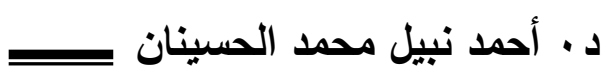 \\ المقاصد الشرعية المرعية \\ في تحقيق التكامل في المجالات الاقتصادية" \\ دراسة فقهية تأصيلية
}

دـ - أحمد نبيل محمد الحسينان(")

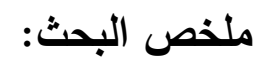

الحمد لله رب العالمين، والصلاة والسلام على أثرف الأنبياء والمرسلين، نبينا محمد وعلى آله وصحبه أجمعين، أما بعد:

فتتاول هذا البحث دراسة مقاصد الاقتصاد الإسلامي، وتتاول أيضاً سبل الهيل

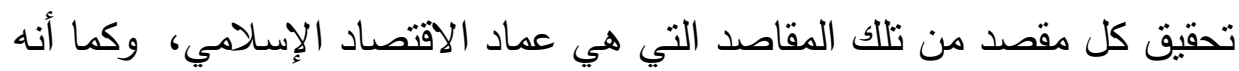

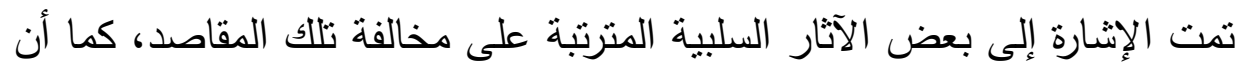

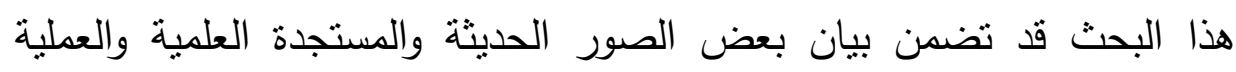

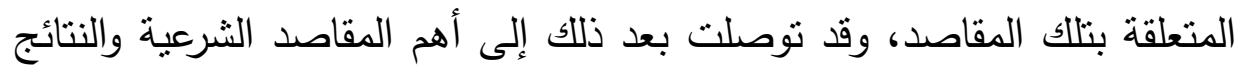
العلمبة والعملية، وهي على ما يأتي: المقصد الأول: تحقيق العدالة الاجتماعية بين أفراد المجتمع، ويتحقى ذلك بما يأتي:

1-تسعير السلع والخدمات بضوابط وشروط تتحقق معها العدالة الاجتماعية بين أفراد المجتمع الواحد. r-تجنب احتكار السلع قدر الإمكان. المقصد الثاني: تحقيق التوازن بين مصلحة الفرد والجماعة، ويتبين ذلك من

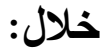

1- تتوع مصارف الزكاة المراد صرفها لبعض أفراد المجتمع المستحقين لها. 
ץ- إعانة الصناع وتدريبهم على الإنتاج والصناعة بما يعود نفعه على أفراد

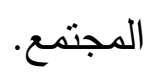

r- إقرار مبدأ الملكية المزدوجة، ويدخل في ذلك:

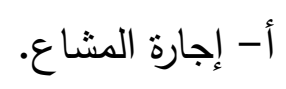

ب- استغلال الثروات الطبيعية، ومن نلك الثروات على وجه الخصوص

$$
\text { الثروات المعدنية والمائية. }
$$

المقصد الثالث: تفعيل الرقابة الذاتية في المعاملات المالية، ويكون ذلك بما

$$
\text { يأتي: لفئ: لفعيل }
$$

1- تجنب الغش في المعاملات المالية بصورها القديمة والحديثة، فمن الصور

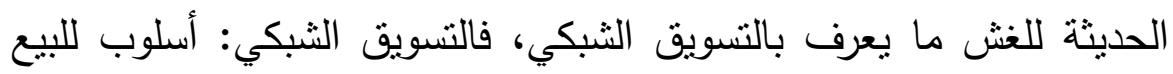

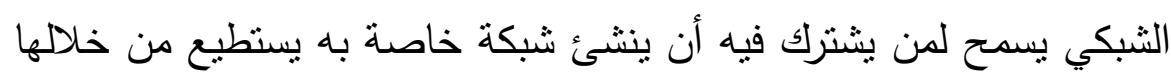

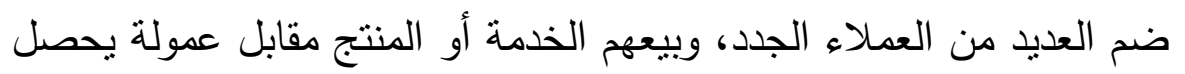

$$
\text { عليها عن كل مشترك. }
$$

r- بيان خطورة غسيل الأموال وأثرها السلبي على الاقتصاد عموماً، فمن الآثار

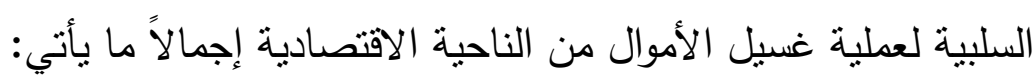

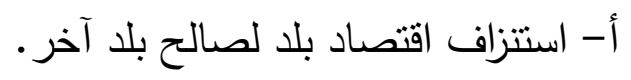

ب- انخفاض الدخل القومي في البلد.

ج- أنه يؤدي إلى زيادة نسبة البطالة.

المقصد الرابع: عمارة الأرض والسعي إلى تئى ندقيق الخير للعباد والبلاد، ويتحقق ذنلك: بالقضاء على البطالة قدر الإمكان. 
בـ د أحمد نبيل محمد الحسينان

المقصد الخامس: تحقيق القوة الاقتصادية والسعي إلى تعزيزها، ويتحقق ذلك بما بأتي:

ا-عمل الرجل بنفسه وتحقيق الكسب من ذلك العمل بما يحقق له ولمجتمعه

الكفاية والاستغناء عن غيره من الدول والأفراد وفي ذلك تتحقق العزة.

r-استغلال الموارد البشرية والطبيعية المتوافرة.

ب-الاهتمام بالابتكارات والعلوم الحديثة التي يكون لها الأثر الإيجابي في تحقيق

النماء الاقتصادي. 


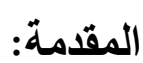

فإن اله تعالى ما خلق هذا الخلق العظيم إلا لحكمة عظيمة إلا وهي عبادته

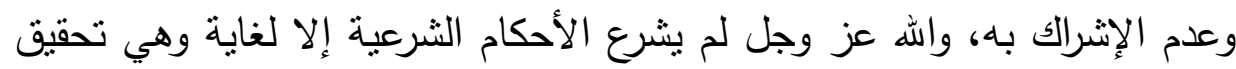

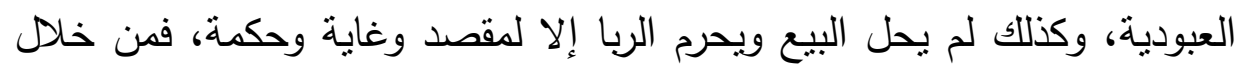

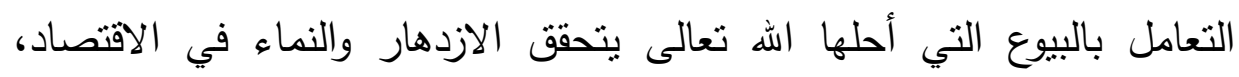

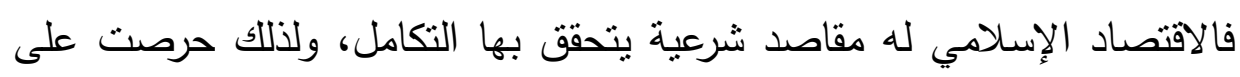
البحث في هذا الموضوع الذي أراه جديراً بالبحث والاهنمام وهو:

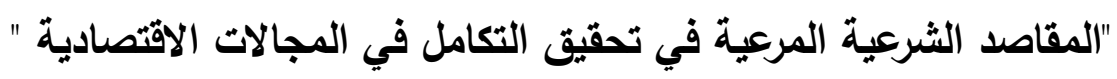

\section{"دراسة فقهية تأصيلية"}

ومن خلال إعدادي لهذا البحث لم أواجه ولله الحمد مشاكل، إلا أن هذالهة

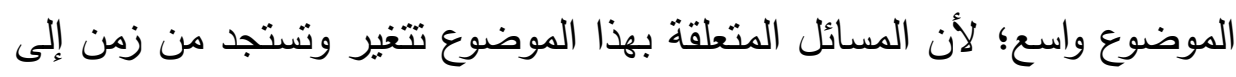

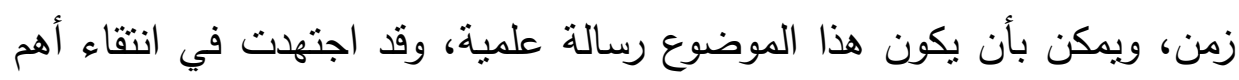

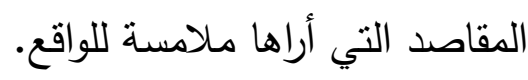
أهمية الموضوع وأسباب اختياره: ا-بيان المقاصد والمرادات التي أرادها الثارع في الاقتصاد الإسلامي.

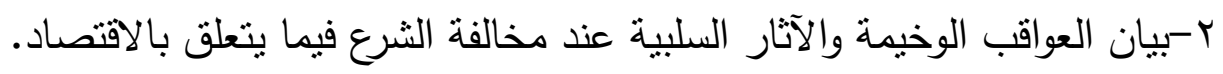

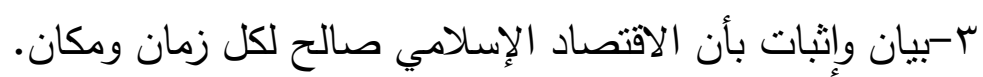

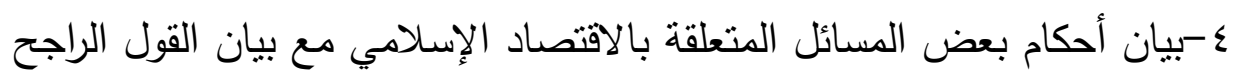
الذي تتحقق به المصلحة. ه-إثبات بأن الثريعة الإسلامية تدعو إلى النطور ومواكبة أسبابه من الناحية

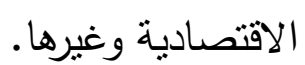


د. • أحمد نبيل محمد الحسينان حـــ

أهداف البحث:

1- السعي إلى تحقيق النمو الاقتصادي بما يكون له الأثز في حصول الازدهار • والتطور

r- بذل الجهد من أجل تحقيق تلك المقاصد الموافقة للشريعة الإسلامية. r- تسليط الضوء على تلك المقاصد ونشرها بين أفراد المجتمع؛ حتى يدرك أفراد المجتمع مدى أهمية الاقتصاد الإسلامي ومقاصده، ويتعاونون في تحقيقها.

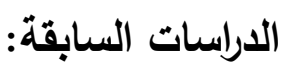
بعد التبعع والاستقراء لم أجد بحثاً مستقلاً يتحدث عن مقاصد الاقتصاد الإسلامي، ولم أجد بحثناً مستقلاً يؤكد أن الاقتصاد الإسلامي سبب لتحقق التكامل في المجالات الاقتصادية.

\section{منهج البحث وهو على ما يأني:}

ا-تصوير المسألة المراد بحثها تصويراً دقيقاً قبل بيان حكمها؛ ليتضح المقصود

$$
\text { من دراستها. }
$$

r-إذا كانت المسألة من مواضع الاتفاق فأذكر حكمها بدليله مع توثيق الاتفاق من مظانه المعتبرة. س-إذا كانت المسألة من مسائل الخلاف فأتبع الآتي: أ-تحرير محل الخلاف إذا كانت بعض صور المسألة محل خلاف وبعضها محل اتفاق. ب-ذكر الأقوال في المسألة، وبيان من قال بها من أهل العلم، ويكون عرض الخلاف حسب الاتجاهات الفقهية. ج-الاقتصار على المذاهب الفقهية المعتبرة. د-توثيق الأقوال من مصادرها الأصلية. هـ-استقصاء أدلة الأقوال مع بيان وجه الدلالة، وذكر ما يرد عليها من 


\section{المقاصد الثرعية المرعية}

$$
\text { و و-الترجيح مع بيان سببه. }
$$

ع-الاعتماد على أمهات المصادر والمراجع الأصلية في التحرير والتوثيق

$$
\text { والتخريج على قدر المسنطاع. }
$$

ه-التركيز على موضوع البحث وتجنب الاستطراد.

$$
\text { 7-العناية بضرب الأمتلة، خاصة الواقعية. }
$$

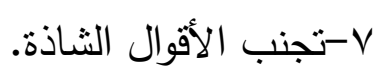

1-العناية بدراسة ما جد من القضايا مما له صلة واضحة بالبحث.

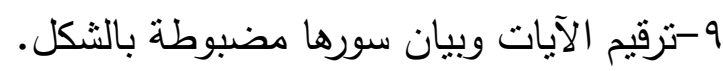

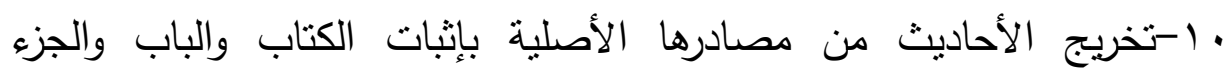

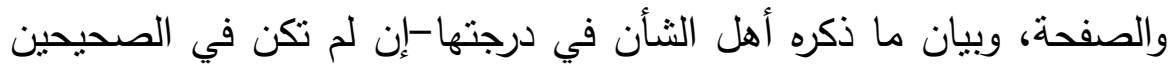

أو أحدهما-فإن كانت كذلك فأكتفي حينئذ بتخريجها منهما. 11-تخريج الآتار من مصادرها الأصلية والحكم عليها.

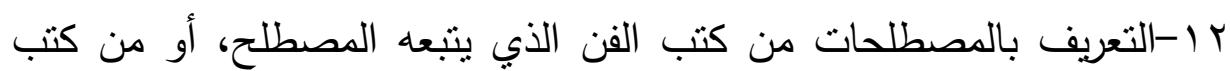

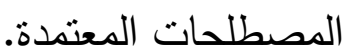

با-توثيق المعاني من معاجم اللغة المعتمدة وتكون الإحالة عليها بالجزء والصفحة. ـ ا-العناية بقواعد اللغة العربية والإملاء وعلامات الترقيم، ومنها علامات التتصبص للآيات الكريمة وللأحاديث الثريفة . 10 - 10 تكون الخاتمة متضمنة أهم النتائج. 
د. • أحمد نبيل محمد الحسينان حـــ

خطة البحث: - 2

قسمت البحث إلى مقدمة ومبحث تمهيدي ومبحث وخاتمة تتضمن أهم نتائج

البحث، ثم المصادر والمراجع:

المبحث التمهيدي: في بيان مفردات عنوان البحث، وفيه سبعة مطالب:

المطلب الأول: في بيان معنى المقاصد لغةً واصطلاحاً.

المطلب الثاني: في بيان معنى الثرعية لغة واصطلاحاً.

المطلب الثالث: في بيان معنى المقاصد الثرعية بالمعنى المركب.

المطلب الرابع: في بيان معنى التكامل.

المطلب الخامس: في بيان معنى الاقتصاد لغةً واصطلاحاً.

المطلب السادس: في بيان معنى التكامل الاقتصادي بالمعنى المركب.

المطلب السابع: في بيان عنوان البحث بالمعنى المركب.

مبحث: في بيان مقاصد الاقتصاد الإسلامي، وفيه تمهيد وخمسة مطالب.

المطلب الأول: في بيان المقصد الأول، وهو تحقيق العدالة الاجتماعية بين

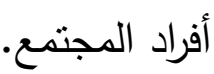

المطلب الثاني: في بيان المقصد الثاني، وهو تحقيق التوازن بين مصلحة

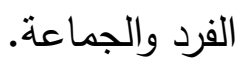

المطلب الثالث: في بيان المقصد الثالث، وهو تفعيل الرقابة الذاتية في

المعاملات المالبة.

المطلب الرابع: في بيان المقصد الرابع، وهو عمارة الأرض والسعي إلى تحقيق الخير للعباد والبلاد.

المطلب الخامس: في بيان المقصد الخامس: وهو تحقيق القوة الاقتصادية

$$
\text { المالسي إلى تعزيزها. }
$$




\section{المبحث التمهيدي}

في بيان مفردات عنوان البحث، وفيه سبعة مطالب:

المطلب الأول: في بيان مغنى المقاصد لغةً واصطلاحاً. المقاصد في اللغة:

جمع مقصد هو إتيان الثيء الثيء (1). والمقاصد في الاصطلاح:

$$
\text { المعاني والحكم المرتبطة بالتشريع(؟). }
$$

المطلب الثاني: في بيان معنى الثرعية لغةً واصطلاحاً. الشرعية في اللغة:

مأخوذة من الثريعة، والثريعة هي الظهور والوضوح (广).

$$
\text { الثرعية في الاصطلاح: }
$$

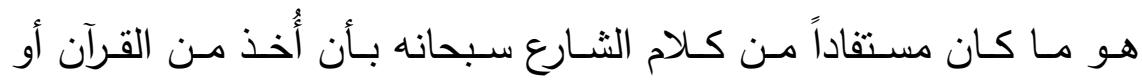

المطلب الثالث: في بيان معنى المقاصد الثرعية بالمعنى المركب:

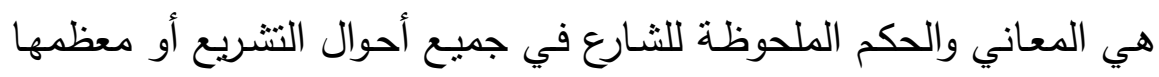
بحيث لا تختص ملاحظاتها في نوع خاص من أحكام الثريعة(ه). المطلب الرابع: في بيان معنى التكامل:

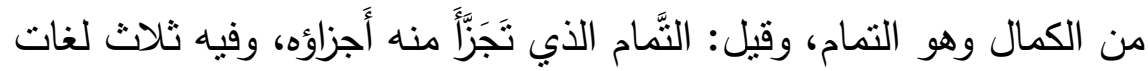

كَتَل الثَيء يَكْمُل وكَمِل وكَمُل كَمالاً وكُمولاً (َ).

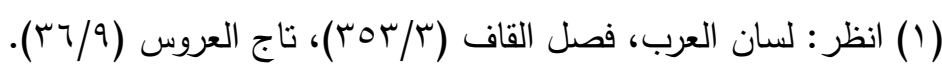

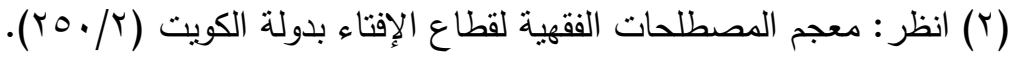

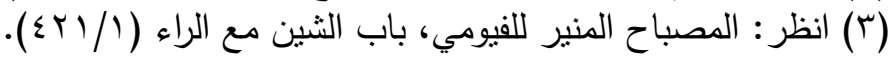

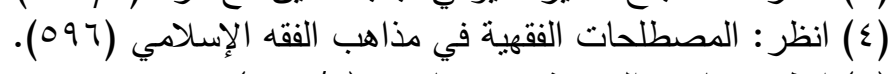

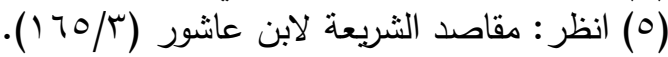

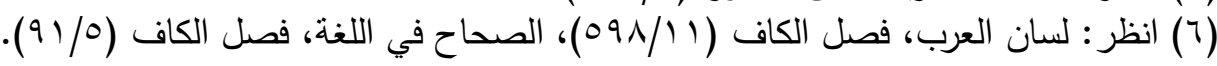

$$
\begin{aligned}
& \text {-rчะ- }
\end{aligned}
$$




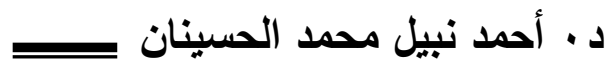

المطلب الخامس: في بيان معنى الاقتصاد لغةً واصطلاحاً:

الاقتصاد في اللغة:

من اقتصد بمعنى استقام، يقال: فلان اقتصد في أمره أي استقام في

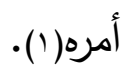

الاقتصاد في الاصطلاح:

هو التوسط بين طرفي الإفراط والتفربط، حيث إن له طرفين هما الإفراط

والتقريط(r).

المطلب السادس: في بيان معنى التكامل الاقتصادي بالمعنى المركب:

التكامل الاقتصادي:هي عملية تحقيق الاعتماد المتبادل بين اقتصاديات

مجموعة من الدول، تتحدد درجاتها المتصاعدة(ץ).

المطلب السابع: في بيان عنوان البحث بالمعنى المركب:

عنوان البحث هو :

"المقاصد الثرعية المرعية في تحقيق التكامل في المجالات الاقتصادية"،

أي تلك المقاصد التي أرادها الثارع والتي تكون سبياً في تحقيق التكامل في المجالات الاقتصادية، وسبل تحقيق تلك المقاصد، من حيث فعل ما ينبغي فعله وترك ما ينبغي تركه.

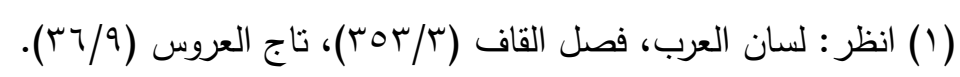

$$
\begin{aligned}
& \text { (Y) انظر : معجم المصطلحات المالية والاقتصادية (YY) (Yr). }
\end{aligned}
$$

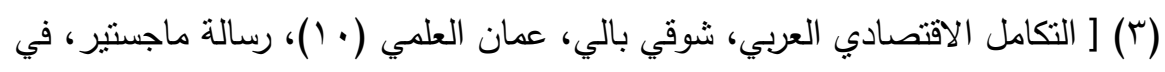

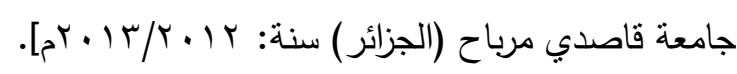

$$
\begin{aligned}
& \text { - r } 70-
\end{aligned}
$$


الاقتصاد الإسلامي: هو عبارة عن دراسة سلوك الإنسان وعلاقته بالموارد

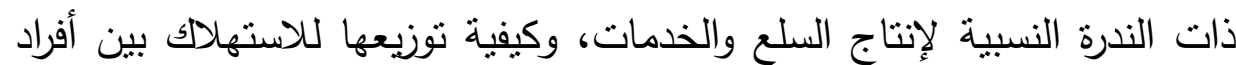
(المجتمع(')• وللاقتصاد الإسلامي مقاصد نكون الغاية منها: جلب المصالح ودرء الدفاسد،

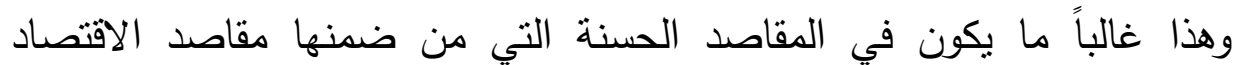
الإسلامي ومن تللك المقاصد خمسة وهي: المقصد الأول: تحقيق العدالة الاجتماعية بين أفراد المجتمع. المقصد الثاني: تحقيق التوازن بين مصلحة الفرد والجماعة. المقصد الثالث: تفعيل الرقابة الذاتية في المعاملات المالية. المقصد الرابع: عمارة الأرض والسعي إلى تحقيق الخير للعباد والبلاد. المقصد الخامس: تحقيق القوة الاقتصادية والسعي إلى تعزيزها. المطلب الأول: في بيان المقصد الأول:

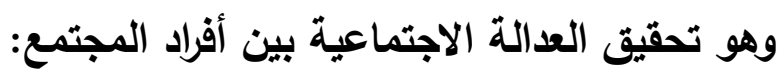

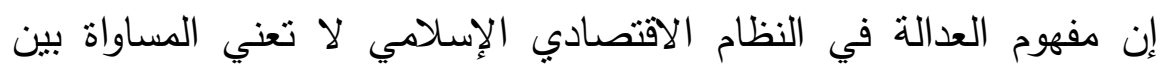

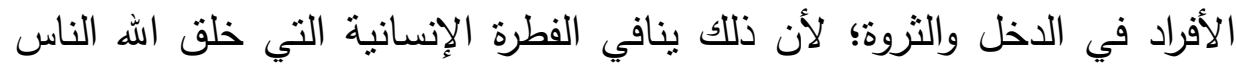

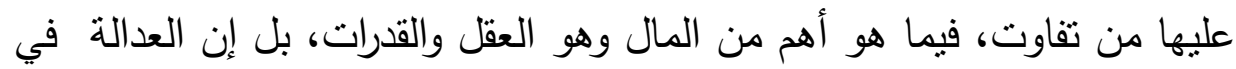

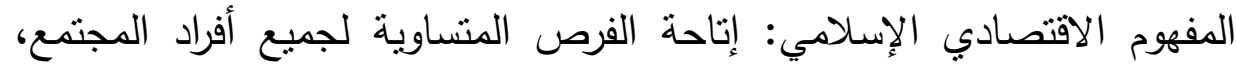

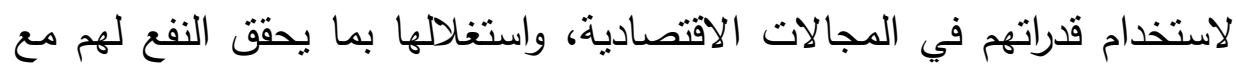

$$
\text { (1) انظر : الأسس النظرية للاقتصاد الإسلاهي (·r). }
$$


د. • أحمد نبيل محمد الحسينان عــــ

الاهتمام بالفئات الغير قادرة على الكسب، بما يكفل لهم مستوى معيشي

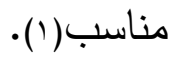

ومن خصائص الاقتصاد الإسلامي أنه يحفظ حقوق الفرد والمجتمع؛ وذلك

بأن النماء المالي يكون عن طريق الاثتغال بالمكاسب وتبادل المنافع، بخلاف غيرها من النظم الاقتصادية التي يكون نماؤها بالغالب عن طريق قطع المكاسب والاستئثار بالمنافع.

ويمكن القول بأن الاقتصاد الإسلامي يسعى إلى تحقيق العدالة الاجتماعية بين أفراد المجتمع من خلال سن ما يكون سبباً في تحقيقها، ويكون ذلك من خلال

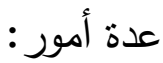

الأمر الأول: تسعير السلع والخدمات بضوابط وشروط تتحقق معها العدالة الاجتماعية بين أفراد المجتمع الواحد: فقبل بيان هذا الأمر لابد من بيان ما هو التسعير، وما هو الحكم الشرعي في التسعير ، وبيان مدى تأثنر التسعير على الاقتصاد الإسلامي. أولاً: تعريف التسعير لغةً واصطلاحاً: التسعير في اللغة:

$$
\text { تقدير السعر (r). (1) - (ب) }
$$

\section{التسعير في الاصطلاح:}

أن يقوم ولي الأمر بتحديد أسعار الحاجات، سواء كانت أعياناً أو منافع،

وإجبار أربابها على بيعها بالسعر المحدد(r).

(1) انظر : الأسس النظرية للاقتصاد الإسلامي (ع (1).

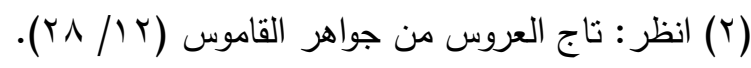

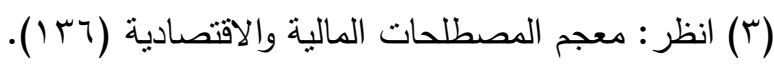




\section{المقاصد الثرعية المرعية - (المية \\ ثانياً: حكم التسعير : التماهن}

اختلف أهل العلم في حكم التسعير على قولين:

القول الأول: يكره التسعير ، وبه قال أبوحنيفة (1).

أدلة هذا القول:

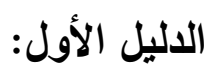

عن أنس بن مالك كرضي اله عنه- قال: قال الناس: با رسول اله غلا

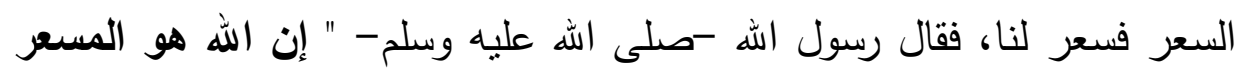
القابض الباسط الرازق، وإني لأرجو أن ألقى الله وليس أحد منكم يطالبني

بمظمة في دم ولا مال "(r).

وجه الدلالة: أن الصحابة قد طلبوا التسعير من رسول اله -صلى الله عليه

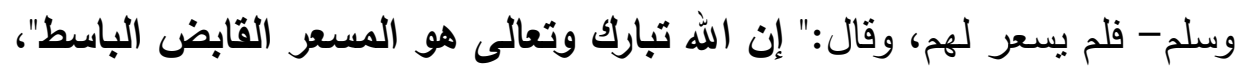

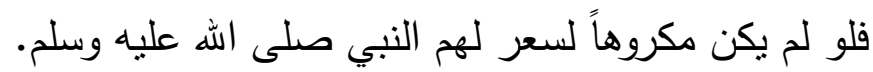

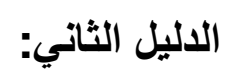

لأن الثمن حق العاقد فلا ينبغي له أن يتعرض لحقه إلا إذا تعدى أرباب

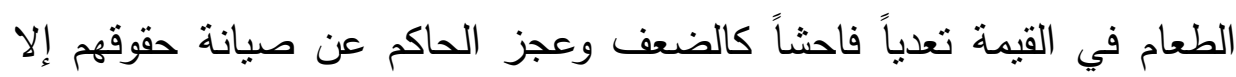
بالتسعير ، فلا بأس حينئذ بالتسعير بمشورة أهل الخبرة(ب).

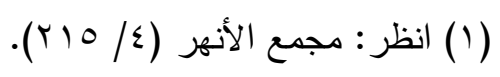

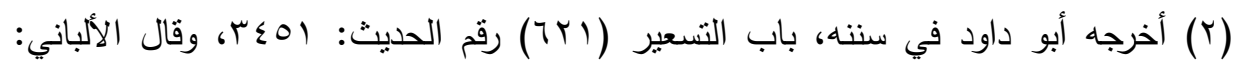

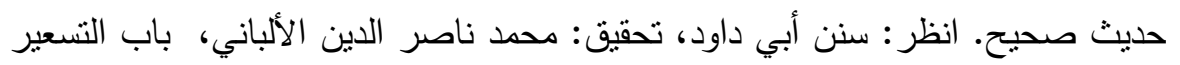

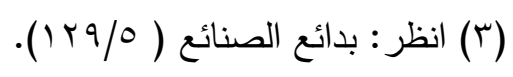


د. • أحمد نبيل محمد الحسينان عـ

القول الثاني: يحرم التسعير مطلقاً، وبه قال مالك(()، والثنافعي(؟)، وأحمد(؟).

أدلة هذا القول:

الاليل الأول:

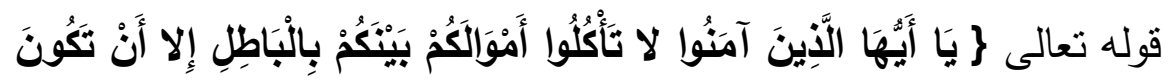

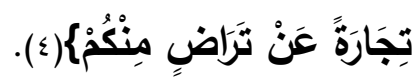

وجه الدلالة: أن الله تعالى قد نهى من أن بتعاطى الناس الأسباب المحرمة

في اكتساب الأموال، بخلاف المتاجرة المشروعة التي تكون عن نراض من البائع

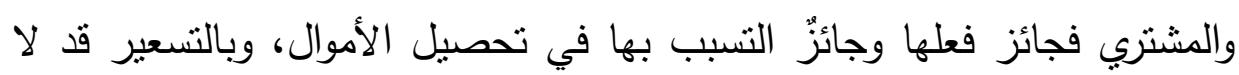
يرضى المشتري بذلك الثنن، ولكنه يجبر على شرائه، فيكون قد فُقد شرطاً من

$$
\text { شروط البيع ألا وهو الرضا(0). }
$$

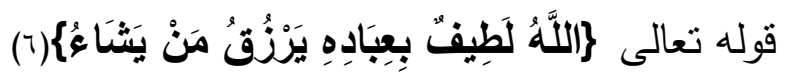

وجه الدلالة: أن في التسعير حجر على صاحب السلعة(v).

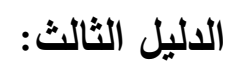

عن أنس بن مالك - رضي الله عنه- قال: قال الناس: يا رسول الله غلا

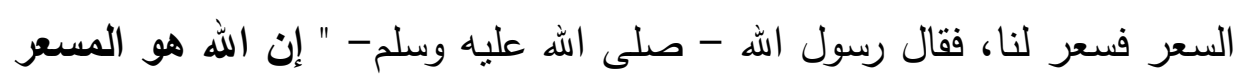

$$
\begin{aligned}
& \text { (1) انظر: الاستذكار لابن عبد البر (·r/Y)، القوانين الفقهية (179). }
\end{aligned}
$$

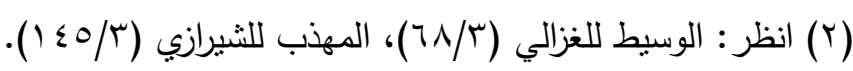

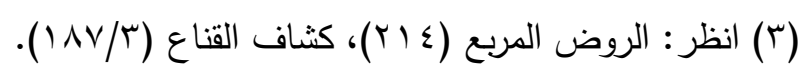

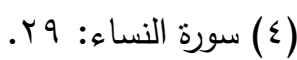

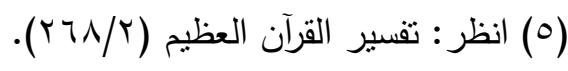

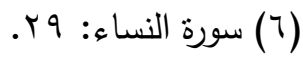

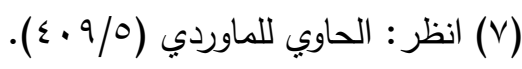


القابض الباسط الرازق، وإني لأرجو أن ألقى الله وليس أحد منكم يطالبني

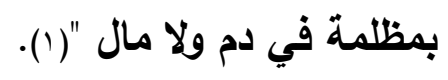

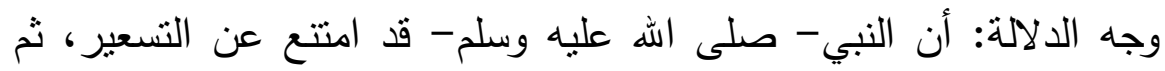
ختم قوله صلى الله عليه وسلم بقوله "وليس أحد منكم يطالبني بمظلمة فى دم ولا لانه

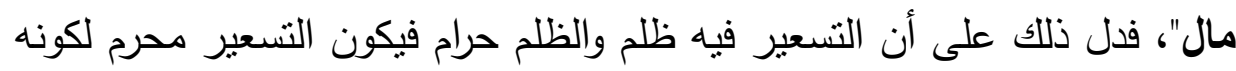

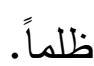

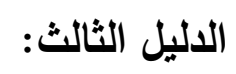

لأن تصرف الإمام في الأسعار يحرك الرغبات ويفضي إلى القحط(؟).

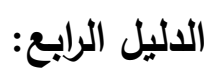

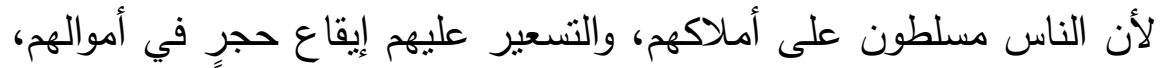

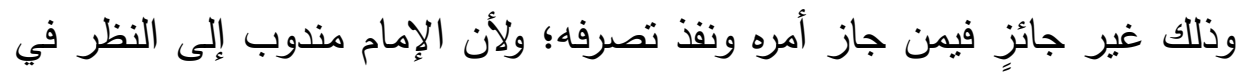

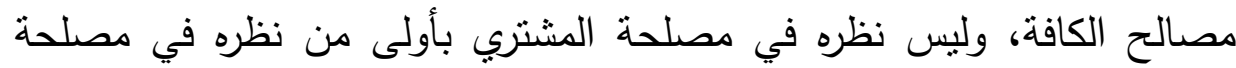

$$
\text { البائع لوفور الثنا(ץ). }
$$

القول الثالث: وفيه التفصيل: أن التسعير منه ما هو محرم، ومنه ما هو لهو جائز، فإذا تضمن ظلم الناس، وإكراههم بغير حق على البيع بشيء لا يرضونه،

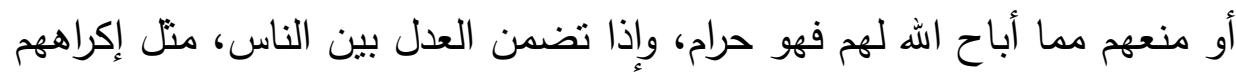

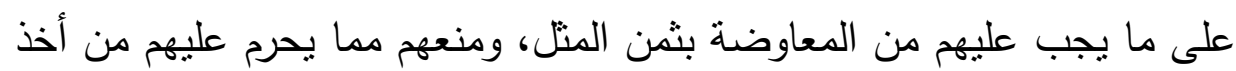
الزيادة على عوض المثل فهو جائز بل واجب، وبه قال ابن القيم(§)، وهذا القول هو القول الوسط والجامع بين أدلة الفريقين، وهو القول الراجح، ولاسيما إذا قيده

$$
\begin{aligned}
& \text { (1) سورة الثورى: } 19 .
\end{aligned}
$$

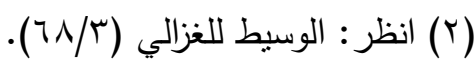

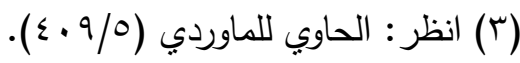

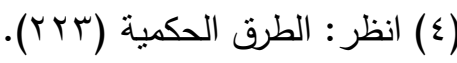


د. د أحمد نبيل محمد الحسينان حس.

الإمام بشروط وضوابط يضعها بما تتحقق بها العدالة الاجتماعية بين أفراد المجتمع، وذلك لما يأتي:

1- أن تسعير السلع والخدمات من ولي الأمر بشروط وضوابط يحد من جشع

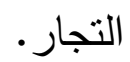

r- أن في تسعير السلع والخدمات بشروط وضوابط يحددها ولي الأمر فيه تحقيق للعدالة الاجتماعية بما يكون فيها مراعاة لأفراد المجتمع؛ وذللك بإنصاف الفئات الأكثز تضرراً من الاختلال الناتج عن التضخم النقدي(1)، ولهذا قال ابن القيم: "وجماع الأمر أن مصلحة الناس إذا لم تتم إلا بالتسعير

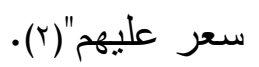

r- أن تسعير السلع والخدمات تعتبر وسيلة من وسائل معالجة التضخم النقدي

$$
\text { الذي قد يضر بالاقتصاد بشكل عام(r). }
$$

$$
\text { الأمر الثاني: تجنب احتكار السلع قر الإمكان: }
$$

فقبل بيان هذا الأمر لابد من بيان ما هو الاحتكار، وحكمه الثرعي، ولابد من بيان مدى تأثير الاحتكار على الاقتصاد الإسلامي. أولاً: تعريف الاحتكار لغةً واصطلاحاً: الاحتكار في اللغة: من حكر وهو النظر والتربص(ء).

(1) التضخم النقدي: هو ارتفاع مطرد في المستوى العام للأسعار.انظر : التضخم النقدي في الفقه الإسلامي (Yo) (Y)

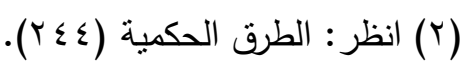

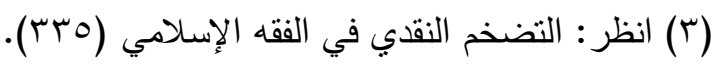

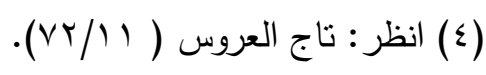




\section{المقاصد الثرعية المرعية \\ الاحتكار في الاصطلاح:}

هو حبس أقوات الناس والبهائم عن البيع ينربص الغلاء شهراً فما زاد فيهما

اشتراه في المصروفية إضراراً بالناس(1). ثانياً: حكم الاحتكار:

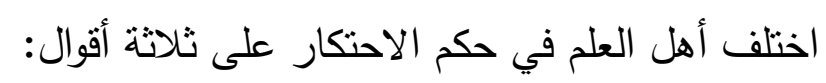
القول الأول: يكره الاحتكار في أقوات الآدميين والبهائم إذا كان ذلإن في في بلد يضر الاحتكار بأهله وبه قال أبوحنيفة (ץ). أدلة هذا القول:

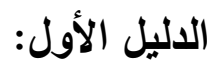

عن عمر بن الخطاب كرضي الله عنه- قال: قال رسول اله صلى اله عليه

وسلم:" الجالب مرزوق والمحتكر ملعون "(r).

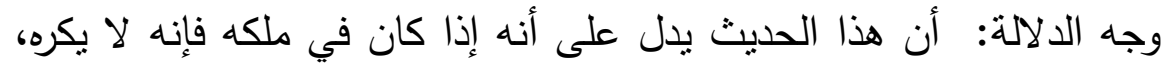

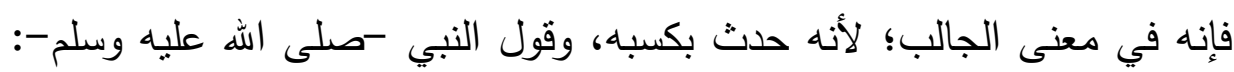

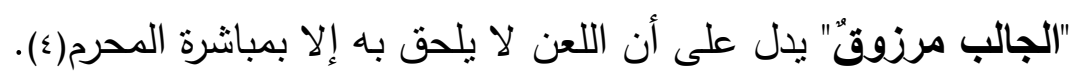

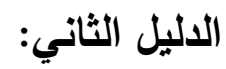

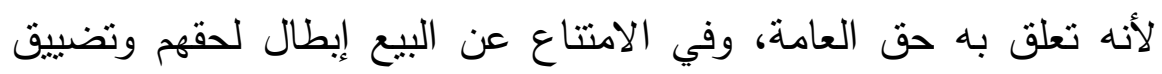

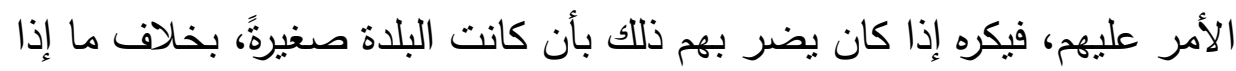

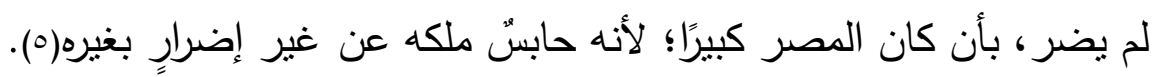

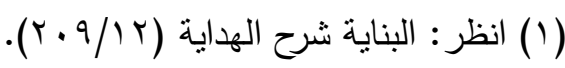

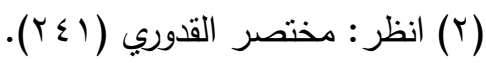

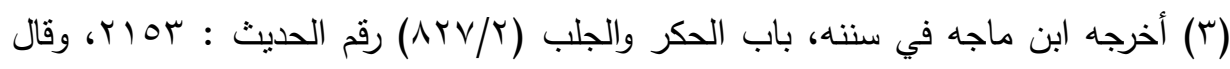

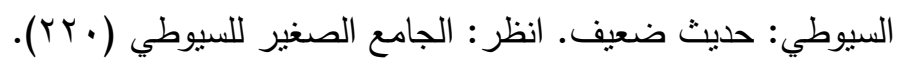

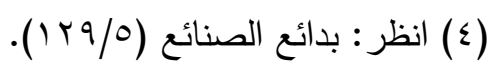

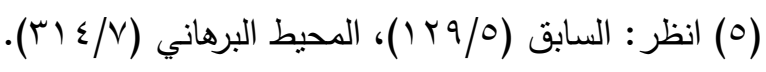


د. أحمد نبيل محمد الحسينان عـــ

القول الثاني: يجوز الاحتكار في الطعام وغيره من الأثياء ما لم يكن فيه

ضرر، وهو القول المشهور عن ماللك(1).

القول الثالث: أن تحريم الاحتكار يختص بالأقوات من الطعام كالتمر

$$
\text { والزبيب والذرة الأرز ، وبه قال الثافعي(r) وأحمد(r). }
$$

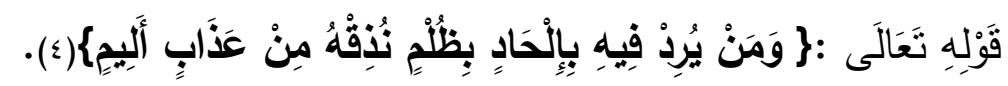

والمراد بالإلحاد هنا: هو احتكار الطعام بمكة، فدل ذللك على تحريم

الاحتكار ؛ لأن العبرة بعموم اللفظ(ه).

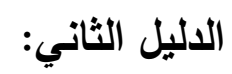

عن عمر بن الخطاب كرضي الله عنه- قال: قال رسول الله صلى الله عليه

و سلم:" الجالب مرزوق والمحتكر ملعون "(ا).

وجه الدلالة: أن في هذا الحديث زجر على من قام بالاحتكار، فإذا كان

كذلك فلإمام الزجر عليه والنهي عنه(v).

الاليل الثالث:

عن أبي هريرة رضي الله عنه: قال: قال رسول الله صلى الله عليه وسلم : حاله

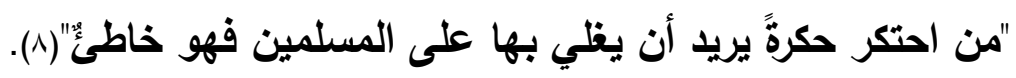

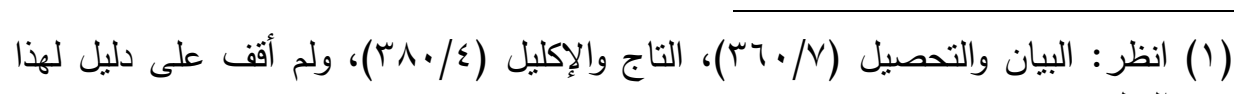

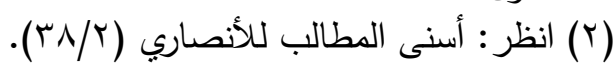

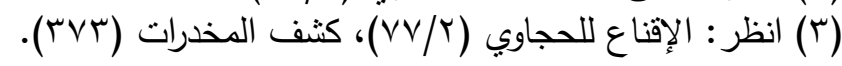

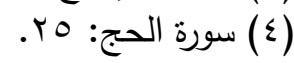

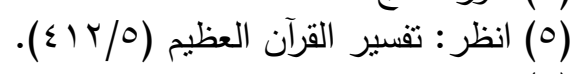

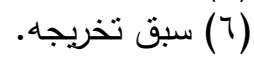

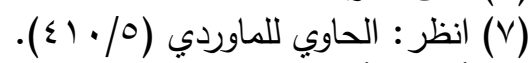

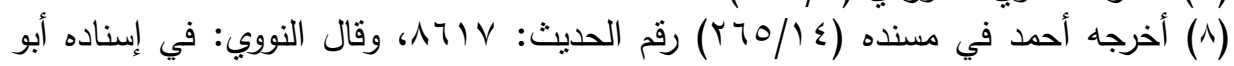

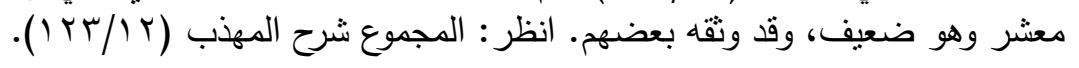


وجه الدلالة: هو قوله :" خاطئ"، والخطأ يكون غالباً في أمر محرم.

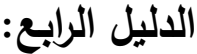

عن سعيد بن المسيب عن معمر قال : قال رسول الهه صلى الله عليه وسلم:

\section{"الا يحتكر إلا خاطئ "(').}

وجه الدلالة: هو قوله صلى الله عليه وسلم :"خاطئ" والخاطئ بالهمزة هو

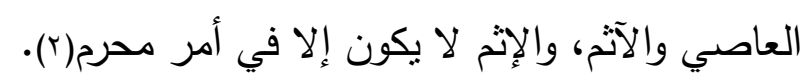

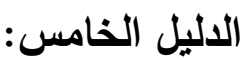

أن الاحتكار عبارة عن عقد فيه خلل، حيث إنه لا جزم فيه، ويتضمن إضراراً

على عامة الناس، ولهذا نهى النبي صلى الله عليه وسلم عنه(r). والقول الراجح في هذه المسألة هو القول الثالث وذللك لما يأتي:

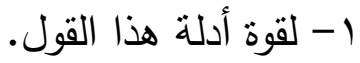

r- لأن الأدلة في هذا القول صريحة في تحريم الاحتكار في الأقوات.

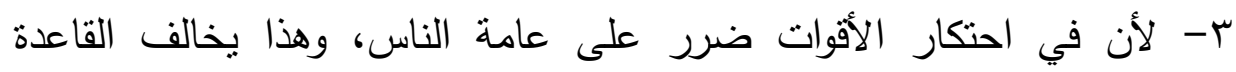

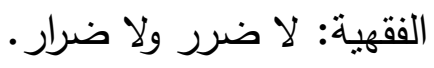

فبناء على ما سبق، يتبين بأن الاحتكار سبب في انكماش الاقتصاد

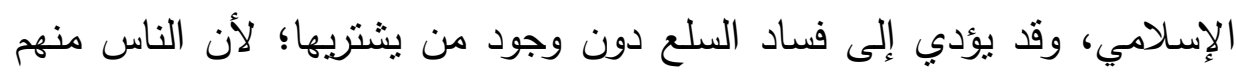

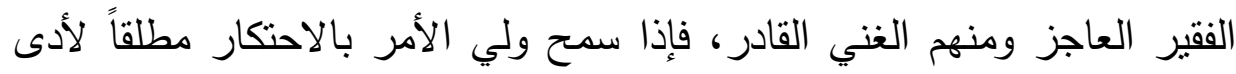

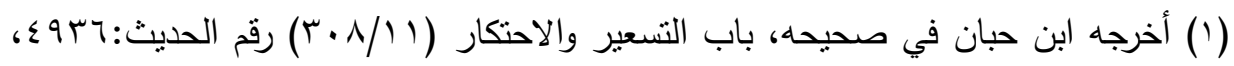

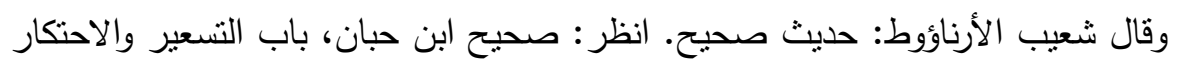

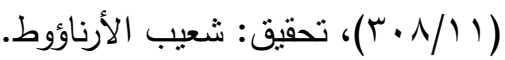

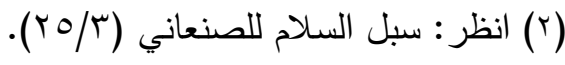

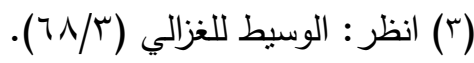




\section{د. د. أحمد نبيل محمد الحسينان عـ}

ذلك إلى منع مشاركة الفقير أو المسكين أو متوسط الحال أحياناً في تتمية الاقتصاد الإسلامي؛ ولهذا ذهب أكثز أهل العلم إلى تحريمها أو القول بكراهة. المطلب الثاني: في بيان المقصد الثاني: وهو تحقيق التوازن بين مصلحة الفرد والجماعة: - وي لبان

التوازن من أبرز الخصائص التي تميز بها الإسلام عن غيره من الأديان

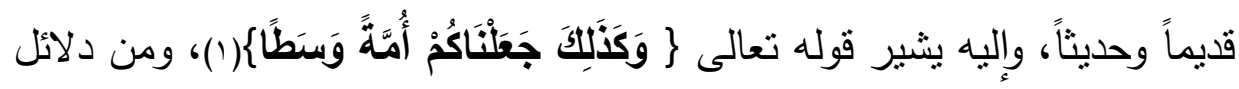
ذلك التقاء الفردية والجماعية في صورة منزنة، تتوازن فيها حرية الفرد ومصلحة الجماعة، وتتكافأ فيها الحقوق والواجبات، وتتوزع فيها المغانم بالعدل فلا إفراط ولا

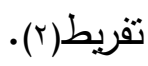

ومن خلال النظر إلى النظام المالي والاقتصادي في الإسلام، يتبين بأن الاقتصاد الإسلامي يراعي كل فرد من أفراد المجتمع غنيهم وفقيرهم، ذكورهم وإناثهم، صغيرهم وكبيرهم، ويتبين ذللك من خلال ما يأني: أولاً: التنوع في مصارف الزكاة:

من خلال النظر إلى مصارف الزكاة، يلاحظ بأنها استوعبت أكثر أفراد المجتمع، فقد استوعبت ثمان أصناف، وهذه الأصناف تتوفر غالباً في كل بلد وفي كل مجتمع وهي ما ذكرها الله تعالى في قوله لرإِنَّمَا الصَّدَقَاتُ لِلْفُقَرَاء

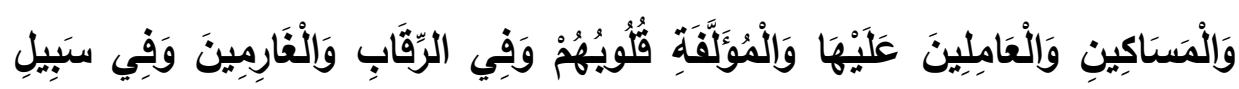

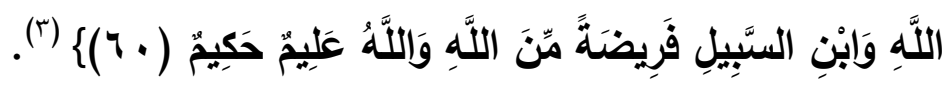

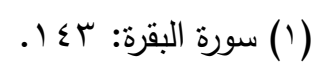

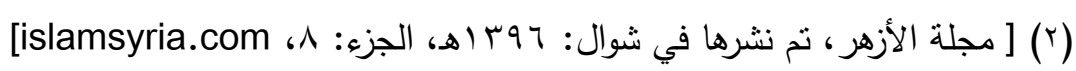

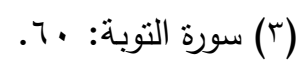




\section{المقاصد الثرعية المرعية}

الأول والثاني: الفقراء والمساكين، وهم في هذا الموضع، صنفه الثفان متفاوتان،

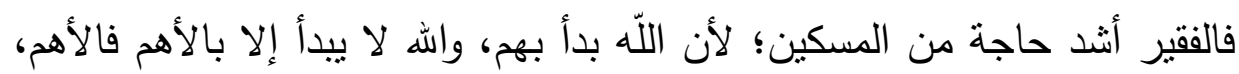

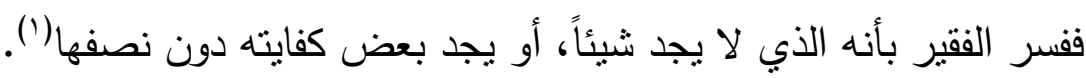

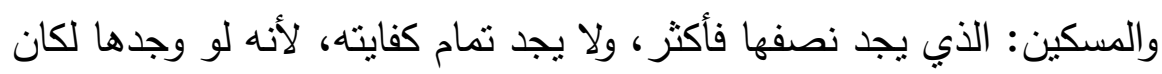

غنياً، فيعطون من الزكاة ما يزول به فقرهم ومسكنتهم (؟).

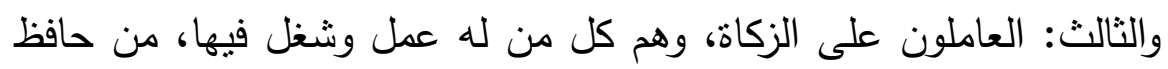

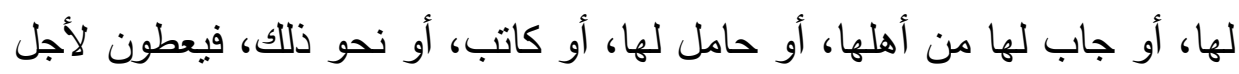
عمالتهم، وهي أجرة لأعمالهم فيها.

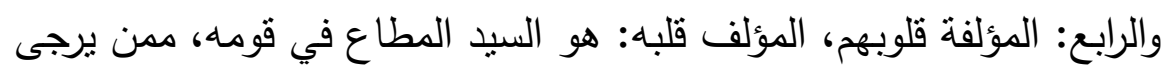
إسلامه، أو يخشى شره أو يرجى بعطيته قوة إيمانه، أو إسلام نظيره، أو جبايتها

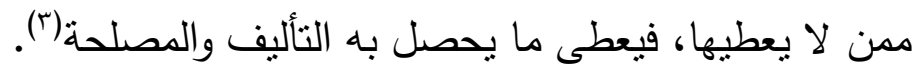
الخامس: الرقاب، وهم الدكانبون الذين قد اشتشروا أنفسهم من ساداتهم، فهم

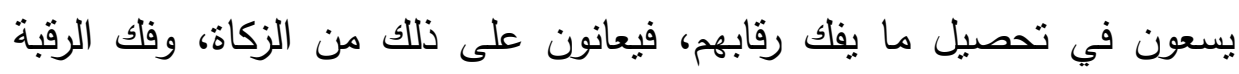

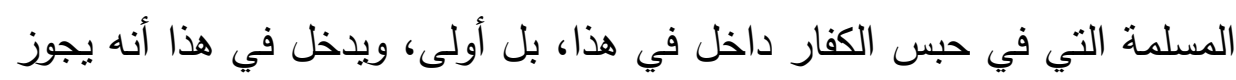
أن يعتق منها الرقاب استقلالاً لاخوله في قوله: السادس: الغارمون، وهم قسمان:

أحدهما: الغارمون لإصلاح ذات البين، وهو أن يكون بين طائفتين من الناس

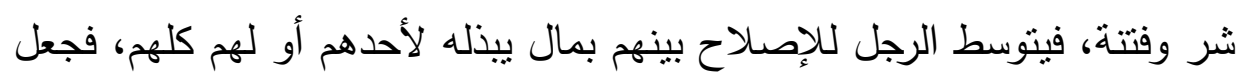

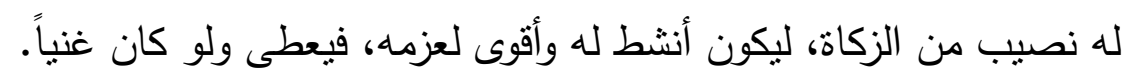

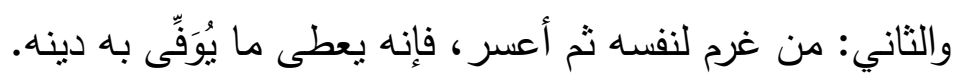

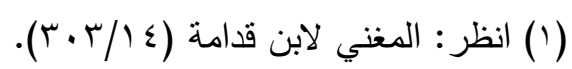

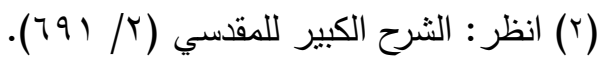

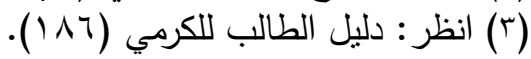
(§) انظر : الروض المربع (9人). 


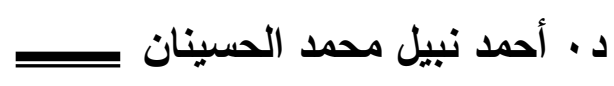

والسابع: الغازي في سبيل اللّه، وهم: الغزاة المتطوعة، الذين لا ديوان لهم، فيعطون من الزكاة ما يعينهم على غزوهم، من ثن سلاح، أو دابة، أو نفقة له ولعياله، ليتوفر على الجهاد ويطمئن قلبه.

والثامن: ابن السبيل، وهو الغريب المنقطع به في غير بلده، فيعطى من الزكاة ما يوصله إلى بلده، فهؤلاء الأصناف الثمانية الذين تدفع إليهم الزكاة

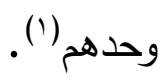

فلو كانت الزكاة محصورة فقط على صنف واحد من ثلإك الأصناف الثثانية لما حصل توازن بين أفراد المجتمع، ولأدى ذلك إلى تفاوت كبير بين الغني والفقير، ولم تتحقق حاجة أغلب أفراد المجتمع غنيهم وفقيرهم ومقيمهم وحاضرهم والغريب المنقطع، فكانت تلك القسمة هي السبيل لتحقيق التوازن بين أفراد

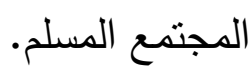
ثانياً: إعانة الصناع وتدريبهم على الإنتاج والصناعة التي تعود بالنفع على

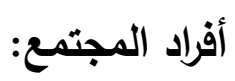
إن تدريب الصناع وإعانتهم على الإنتاج والصناعة من الوسائل المعينة على تحقيق التوازن بين مصلحة الفرد ومصلحة الجماعة، فيكون الفرد الذي لديه دراية وخبرة في صنعة، وسيط يتوسل به إلى النفع لباقي أفراد المجتمع، ومن ثم يتحقق

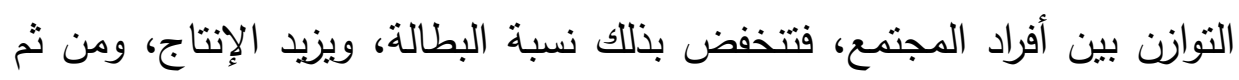
يتحقق النماء الاقتصادي، وهذا ما حث عليه النبي صلى الله عليه وسلم، فعن أبي ذر رضي الله عنه قال: قلت: يا رسول الله أب الأعمال أفضل؟ قال:" الإيمان بالله والجهاد في سبيله"، قال: قلت أي الرقاب أفضل؟، ألهاب قال: "أنفسها عند أهلها وأكثرها ثمنا"، قال : قلت فإن لم أفعل؟ قال : "تعين صاتعاً

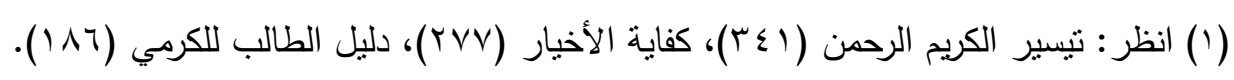


أو تصنع لأخرق"، قال: قلت: يا رسول اله أرأيت إن ضعفت عن بعض العمل،

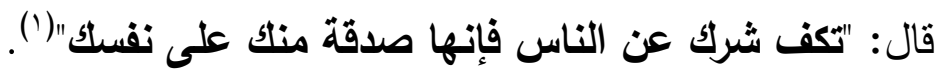
وجه الدلالة من هذا الحديث: هو قوله صلى اله عليه وسلم:" "تعين صانعاً أو تصنع لأخرق":أي ما به معاش الرجل ويدخل فيه الحرفة والتجارة بما يجعله صانعاً بما يجعله يحقق الكسب لعياله.

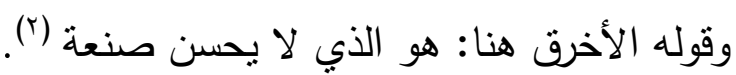

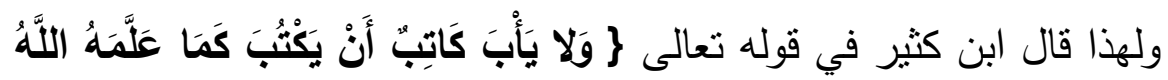

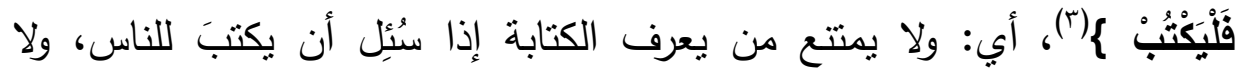

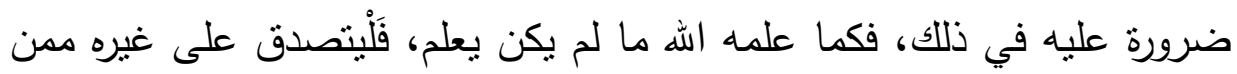

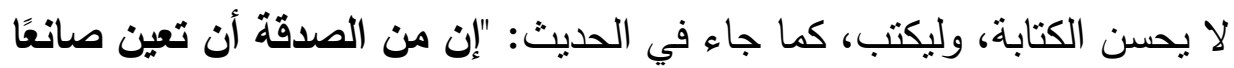

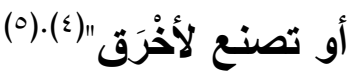

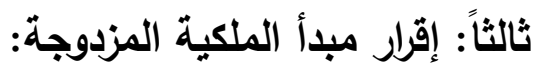
يمكن تقسيم الملكية إلى ملكيتين: الملكية الخاصة والملكية العامة، ويراد

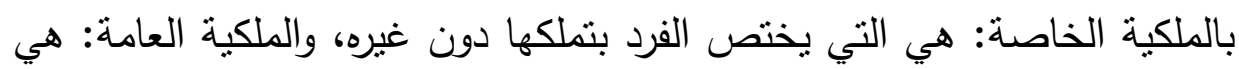

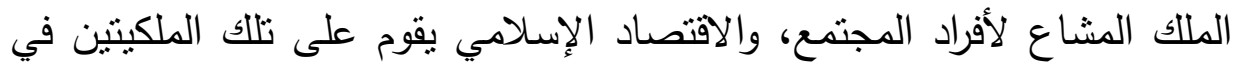

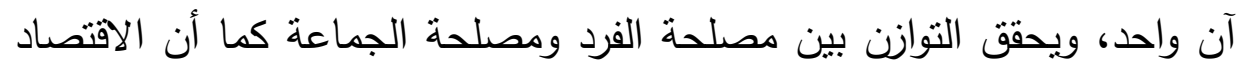

(1) أخرجه مسلم في صحيحه، باب بيان كون الإيمان باله تعالى أفضل الأعمال (آ) رقم

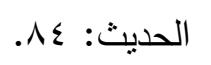

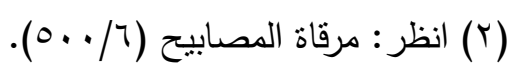

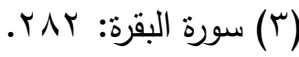

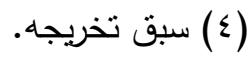

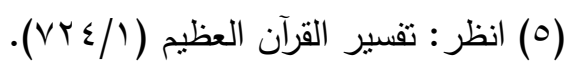


د. د أحمد نبيل محمد الحسينان

الإسلامي يعترف بهاتين المصلحتين طالما لم يكن ثمة تعارض بينهما(') فكان التوفيق بينهما ممكناً ويتبين ذلك من خلال ما يأتي:

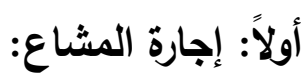

إذا كانت العين المتعاقد على منفعتها مشاعًا، وأراد أحد الثريكين إجارة

منفعة حصته، فإجارتها للشريك جائزة بالاتفاق(؟).

وصورة إجارة المشاع : هو أن يؤجر نصيباً من داره أو نصيبه من دار

مشتركة من غير الشريك أو يؤاجر نصف عبد أو نصف دابة من غير الشريك(ب). وبيان ذلك:

كما لو قال شخص لثريكه: أجرتك نصف الدابة إلى موضع كذا، أو أجرتلك

الدابة لتركبها نصف الطريق، صح ويقتسمان بالزمان (£).

ووجه جواز ذلك: أن في هذه الصورة تقع المهائة بين المستأجر والمؤاجر،

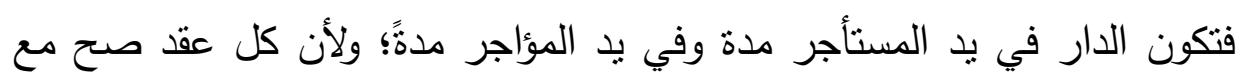

الثريك صح مع غيره كالبيع (0).

مسألة: فيما لو تعارض مصلحة الفرد مع مصلحة الجماعة:

إذا تعارضت مصلحة الفرد مع مصلحة الجماعة في مسألة الملكية المزدوجة

فإنها تقدم مصلحة الجماعة على مصلحة الفرد، ودليل ذلك ما يأني:

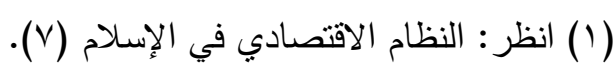

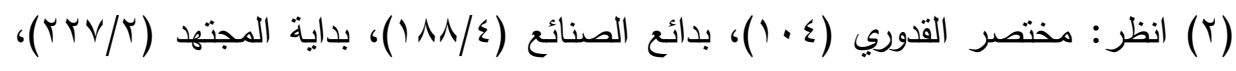

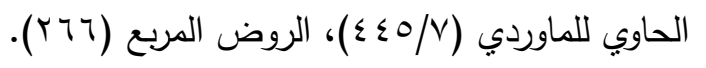

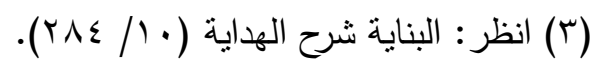

انظر : روضة الطالبين (1) (1) (1).

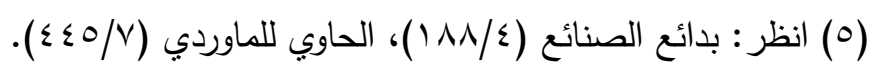


ا - عن أبي هريرة رضي الله عنه قال: نهى رسول الله صلى الله عليه وسلم أن

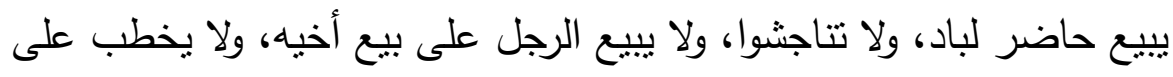

خطبة أخيه، ولا نسأل المرأة طلاق أختها لتكفأ ما في إنائها (1).

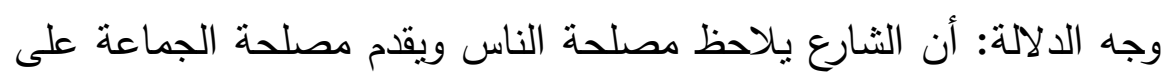

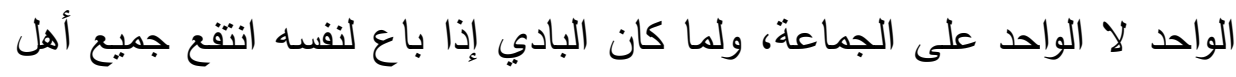

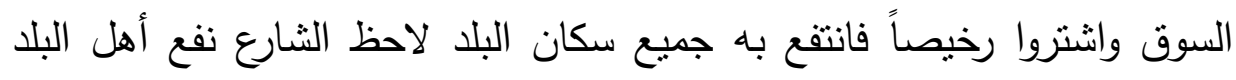
على نفع البادي(r). ץ- عن أبي هريرة رضي الله عنه قال: نهى النبي صلى الله عليه وسلم عن التلقي(ץ)، وأن يبيع حاضر لباد(؟). وجه الدلالة: أن البيع يكون فيه رفق بالناس، ولذلك ورد النهي عن تلقي النه

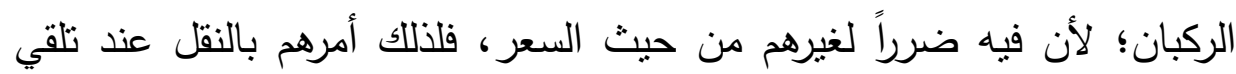
الركبان ليوسعوا على أهل الأسواق(ه). ثانياً: استغلال الثروات الطبيعية، ومن تلك الثروات الثرات على الثى وجه الخصوص الثروات المعدنية والمائية:

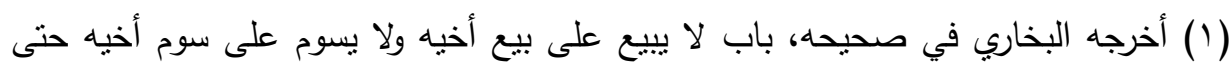

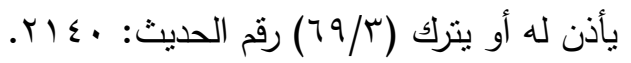

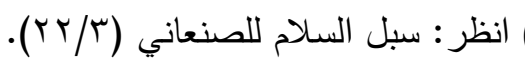

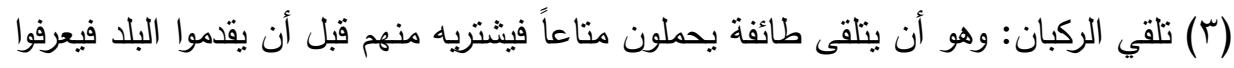

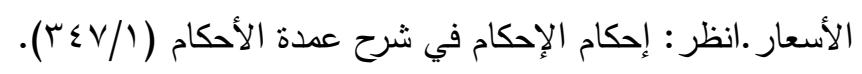

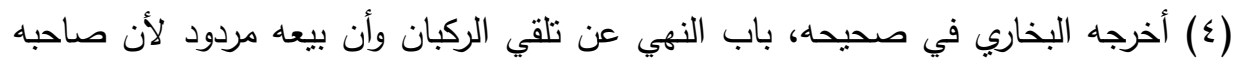

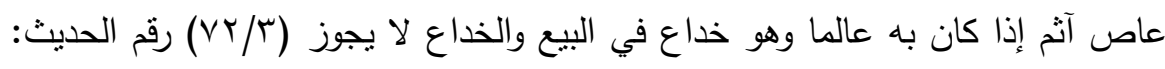




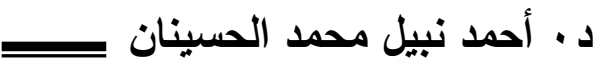

غالباً ما ثقوم الدولة باستغله الثزوات على أحسن وجه لصالح البشرية،

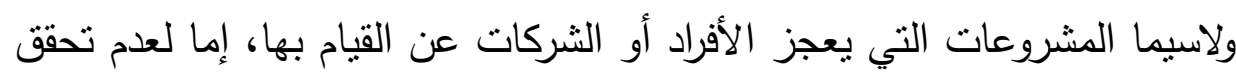
الإمكانيات أو بسبب تكاليفها الباهظة: كبناء المواني وإقامة المدن الصناعية واستغلا الأراضي الثاسعة للزراعة وغيرها، ولكن عندما يكون لبيت مال الدولة

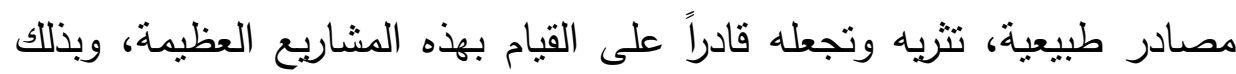
يتحقق التوازن بين مصلحة الفرد ومصلحة الجماعة، وبذلك تتحقق مصلحة الفرد من خلال تلك الثروات، فإذا تحققت مصلحة الفرد فإن ذلك يكون طريقاً لتحقيق مصلحة الجماعة، فلو قلنا بأن الفرد هو الذي له الحق المطلق في استغلال تلك الثروات لتعطلت تلك الثروات، ولما حصلت الفائدة له ولا لغيره، ولهذا ذهب أصحاب المذهب المالكية إلى أن المعادن إذا ظهرت في أرض ليست مملوكة لأحد فإنها تكون ملكاً للاولة، أي تلخل في ملكية الأمة العامة حتى تعم الفائدة

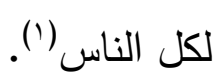
ومن الأمور التي يتحقق فيها التوازن بين مصلحة الفرد ومصلحة الجماعة: الاشتراك في الموارد المائية، فكما هو معلوم بأن الماء مصدر من مصادر الطاقة التي يستغلها كثيرُ من الناس، فالقدرة المائية استخدمت في تشغيل مكنات وآليات منذ آلاف السنين وما زالت، فطاقة المياه الجارية مجانية، ويمكن تحويلها إلى شغل مفيد بسهولة ويسر •

فالقدرة المائية هي استخدام الماء لأداء شغل: كإنتاج الكهرباء أو إدارة

النواعير والطواحين، والقدرة المائية ألطف بالبيئة(؟). وقد بين النبي صلى الله عليه وسلم بأنه ليس للفرد الحق المطلق في الاختصاص بتملك الموارد المائية، فعن أبي خداشٍ عن رجلٍ من أصحاب النبي لهي لهي

$$
\text { (1) انظر : الثرح الكبير للاردير (1) (1) انظر ). }
$$

(r) انظر : القدرة المائية للخطيب (0). 


\section{المقاصد الثرعية المرعية}

صلى الله عليه وسلم قال: قال رسول الله صلى الله عليه وسلم:" المسلمون

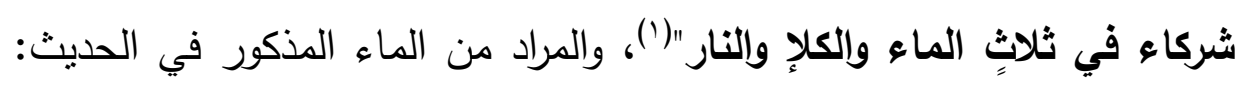

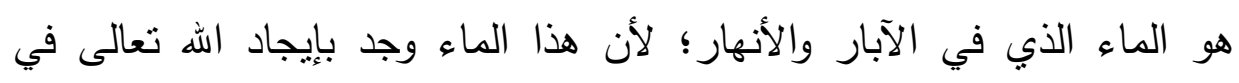

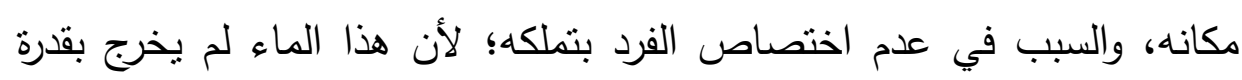

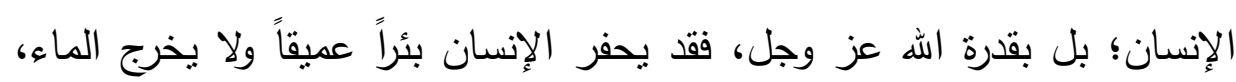
فليس من كده ولا فعله، بل هو سبب فلذلك لا يملكه (؟).

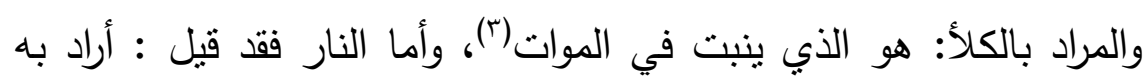

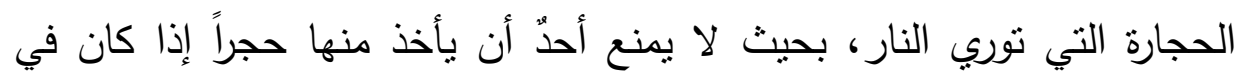

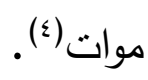

المطلب الثالث: في بيان المقصد الثالث: وهو تفعيل الرقابة الذاتية في

\section{المعاملات المالية:}

من مقاصد الاقتصاد الإسلامي: هو تفعيل الرقابة الذاتية التي أمرنا بها الله

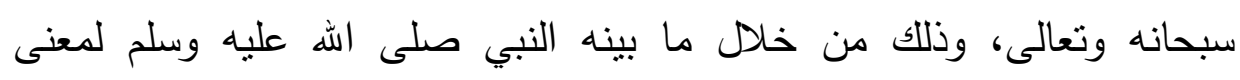

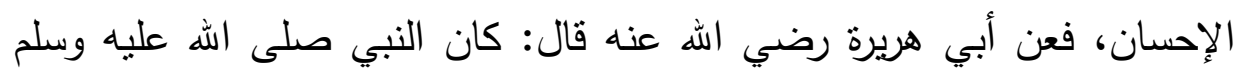

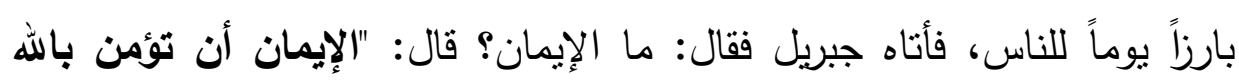

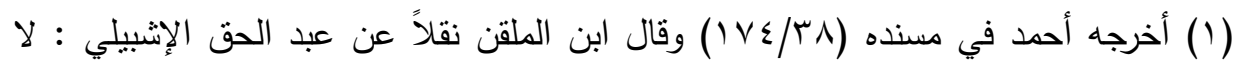

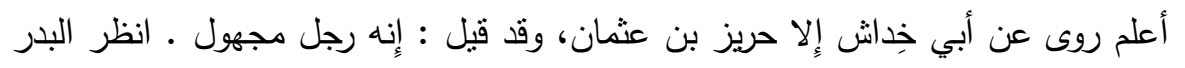

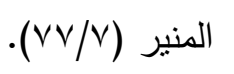

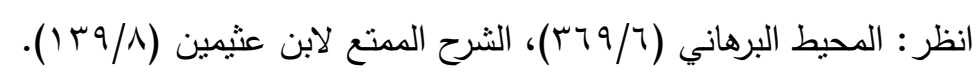

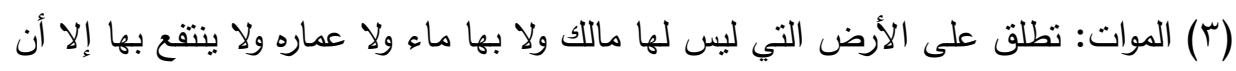

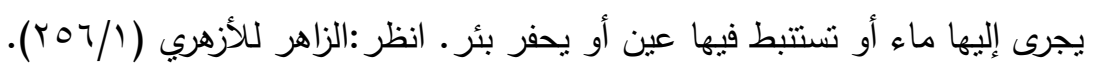

$$
\begin{aligned}
& \text { (؟) انظر: شرح السنة للبغوي (rVq/^). }
\end{aligned}
$$




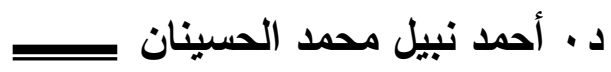

وملائكته ويلقائه ورسله وتؤمن بالبعث". قال: ما الإحسان؟ قال:" أن تعبد الله

كأنك تراه فإن لم تكن تراه فإنه يرالك"( ).

قال القاضي عياض:" هذا الحديث قد اشتمل على شرح وظائف العبادات

الظاهرة والباطنة من عقود الإيمان وأعمال الجوارح وإخلاص السرائر والحفظ من

آفات الأعمال حتى إن علوم الثربعة كلها راجعة إليه"(r).

فإذا لم تتحقق الرقابة الذاتية بالنسبة لأفراد المجتمع سيؤدي ذلك إلى ضياع

الأمانة وقد يؤدي إلى أمور قد لا يحمد عقباها، ومن هذه الأمور :

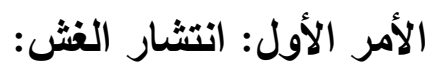

فالغش له نأثثر سلبي في الاقتصاد الإسلامي، ولهذا نهى النبي صلى الهّ

عليه وسلم عن الغش، فعن أبي هريرة رضي اله عنه أن رسول الله صلى اله اله عليه وسلم مر على صبرة طعام فأدخل يده فيها فنالت أصابعه بلالا فقال: "ما هذا يا صاحب الطعام؟" قال: أصابته السماء يا رسول الله، قال:" أفلا جعلته فوق الطعام كي يراه الناس، من غش فليس مني"(r).

فهذا الحديث يدل على تحريم الغش وهو مجمع شرعاً مذموم فاعله عقلاً (ء). وللغش آثار سلبية على الفرد والمجتمع فمن تلك الآثار السلبية للغش في

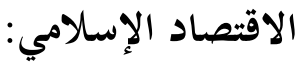

(1) أخرجه البخاري في صحيحه، باب سؤال جبريل النبي صلى الله عليه وسلم عن الإيمان

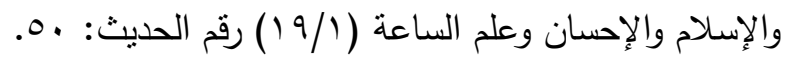

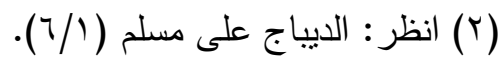

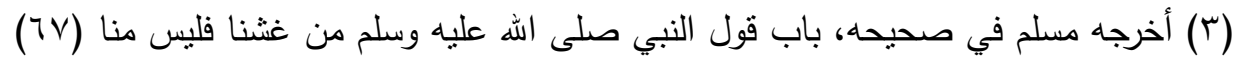

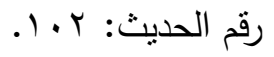

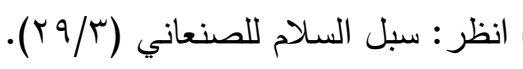


1- فساد أمر المجتمع وانتشار الظلم بين أفراده، ويؤدي أيضاً إلى أخذ الأموال بغير وجه حق، وحصول الربح غير المشروع لمن لا بستحقه لا شرعاً ولا

$$
\text { عقلاً. }
$$

r- أنه يقضي على سبل المؤدية إلى حصول وتبادل المصالح، ويضعف أيضاً سبل تحقيق التعاون المفيد، وذلك لا يتحقى إلا بسلوك الطريق الثرعي المبن الثبني

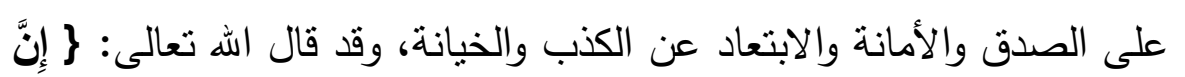

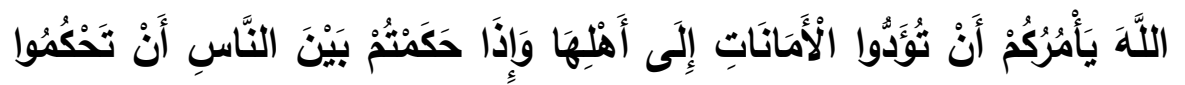

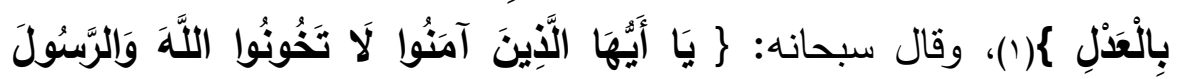

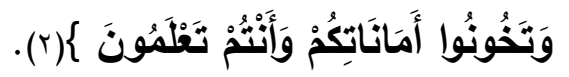

ץ- ظهور الثحناء والبغضاء بين أفراد المجتمع، مما يؤدي إلى انحسار التعاون

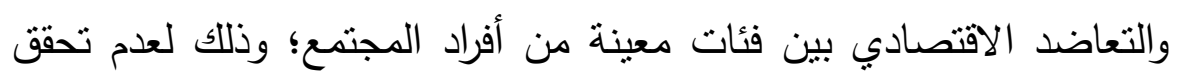

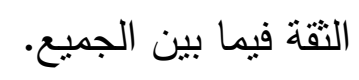

ع - عدم حصول البركة في المعاملات عموماً، ويؤدي أيضاً إلى عدم تحقق لجق السلامة من أكل الحرام، وكذلك يؤدي إلى ظلم المسلم لأخيه، ولهذا قال النبي

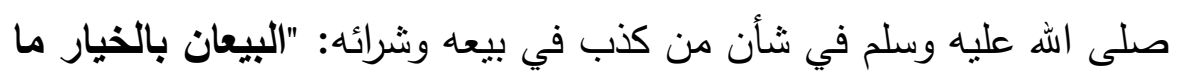

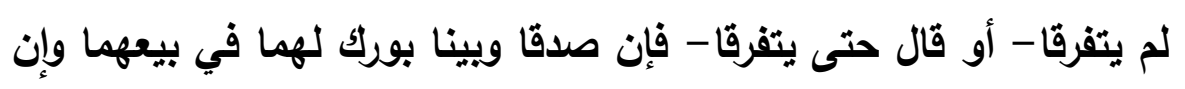

كتما وكذبا محقت بركة بيعهما"(r).

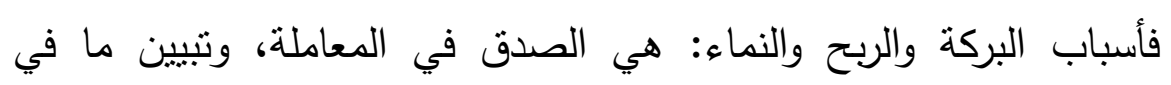
المعقود عليه من عيب أو نقص أو نحو ذلك.

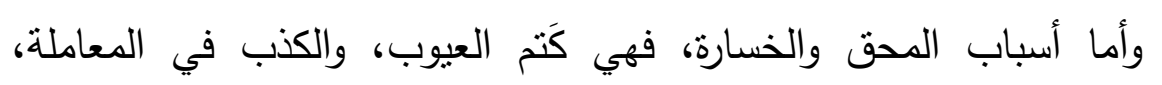

$$
\text { والتّليس. }
$$


د. أحمد نبيل محمد الحسينان

فالصدق والأمانة أسباب حقيقية لحصول البركة في الدنيا بالزيادة والشهرة

$$
\text { بحسن المعاملة، وفي الآخرة بالأجر والثثاب. }
$$

والكذب والخيانة أسباب حقيقية لمحق كسب الحياة، وسبب لسوء المعاملة بين

أفراد المجتمع، وبذلك لا تتحقق ثقة الناس ببعضهم البعض وإقبالهم على بعضهم،

وأعظم من ذلك كله هو حصول الخسارة في الآخرة لمن غش الناس(1).

ومن صور الغش الحديثة في المعاملات المالية ما يعرف بالتسويق الثبكي،

فالتسويق الثبكي: أسلوب للبيع الثبكي يسمح لمن يشترك فيه أن ينشئ شبكة خاصة به يستطيع من خلالها ضم العديد من العملاء الجدد، وبيعهم الخدمة أو لئي المنتج مقابل عمولة يحصل عليها عن كل مشترك، وعرفه بعضهم بأنه نوع من بن بن تسويق المنتجات أو الخدمات مبني على التسويق التواصلي حيث يقوم المستهلك بدعوة مستخدمين آخرين لشراء المنتج في مقابل عمولة، ويحصل أيضاً المستخدم على نسبة في حالة قيام عملاءه بييع المنتج لآخرين بحيث يصبح من على قمة

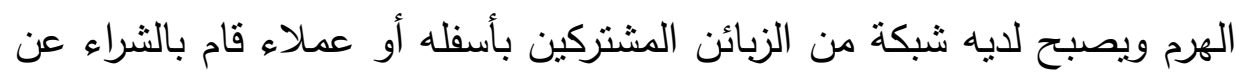

طريقهم(r).

والتسويق الثبكي يجعل أتباعه يأملون بالثراء السريع، لكنهم في الواقع لا يحصلون على شيء؛ وتذهب معظم أموالهم التي نم جمعها من خلالهم إلى بـ بـاء أصحاب الثركة، ولذلك حذر جمع من أهل العلم من هذا التسويق لكونه صورة

من صور الغش التجاري(r).

$$
\text { (1) (انظر : نيسير العلام في شرح عدة الأحكام (r/ ( ) ). }
$$

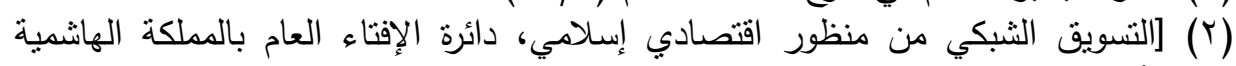

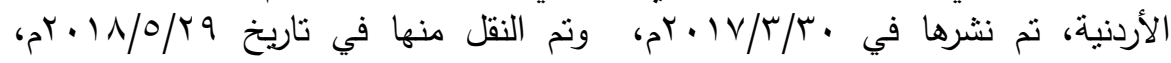

[www.aliftaa.jo

$$
\text { (ץ) انظر : يسألونك عن المعاملات المالية المعاصرة (r/ ( ). }
$$




\section{المقاصد الثرعية المرعية}

وقد أفتت اللجنة الدائمة للإفتاء بالمملكة العربية السعودية بتحريم التعامل

$$
\text { بالتسويق الثبكي لأمور منها: }
$$

أولاً: أنها تضمنت الربا بنوعيه: ربا الفضل وربا النسيئة، فالمشترك يدفع

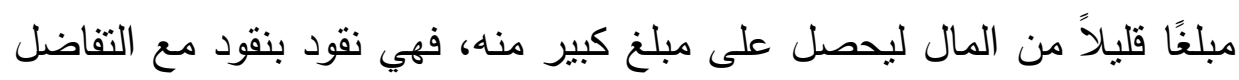

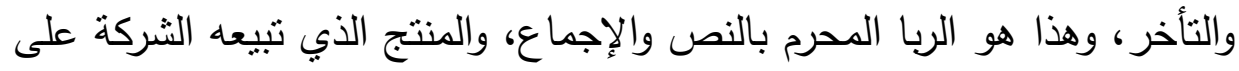

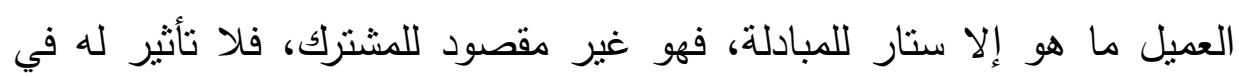
الحكم.

ثانيًا: أنها من الغرر المحرم شرعًا؛ لأن الششرك لا يدري هل ينجح في الهي

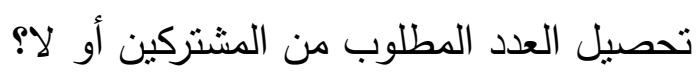

والتسويق الثبكي أو الهرمي مهما استمر فإنه لا بد أن يصل إلى نهاية

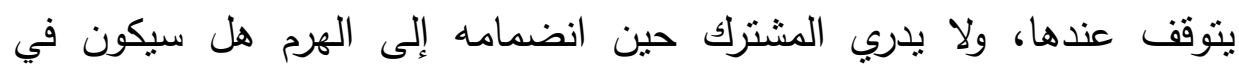

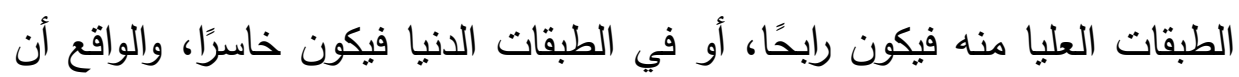

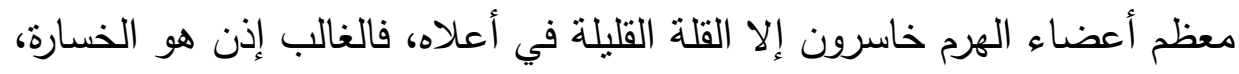

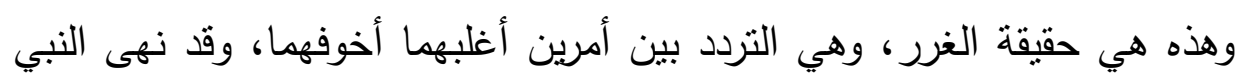

$$
\text { صلى الله عليه وسلم عن الغرر (1). }
$$

ثاثثًا: ما اشتملت عليه هذه المعاملة من أكل الثركات لأموال الناس بالباطل، حيث لا يستقيد من هذا العقد إلا الثركة ومن نرغب العن إعطاءه من

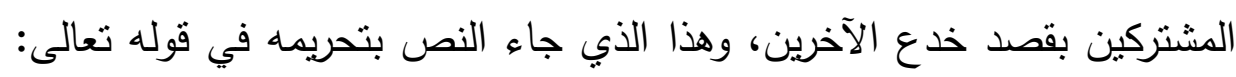

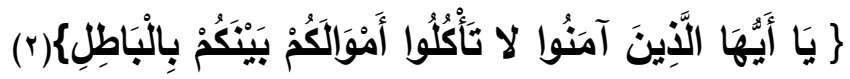

$$
\begin{aligned}
& \text { (1) أخرجه مسلم في صحيحه، باب بطلان بيع الحصاة والبيع الذي فيه غرر (ع (آ) رقم } \\
& \text { الحديث: } 101 \% \\
& \text { (Y) سورة النساء: } 9 \text { Y. }
\end{aligned}
$$


د. د أحمد نبيل محمد الحسينان عـ

رابعًا: ما في هذه المعاملة من الغش والتذليس والتلبيس على الناس، من جهة إظهار المنتج وكأنه هو المقصود من المعاملة والحال خلاف ذللك، ومن جهة إغرائهم بالعمولات الكبيرة التي لا تتحقق غالبًا، وهذا من الغش المحرم شرعًا وقد قال عليه الصلاة والسلام: "البيعان بالخيار ما لم يتفرقا أو قال حتى يتفرقا فإن لهان

صدقا ويينا بورك لهما في بيعهما وإن كتما وكذبا محقت بركة بيعهما "(('.) (r). الأمر الثاني:اتتشار ظاهرة غسيل الأموال: المراد بعملية غسيل الأموال أو تطهيرها أو تبييضها: هو استثمار أو الوهيل استخدام الأموال القذرة المكتشبة من مصادر غير مشروعة(؟). وهذا الاستثمار له آثار سلبية من الناحية الاقتصادية وقد يمتد أثزه على الفرد والمجتمع فمن تلك الآثار السلبية ما يأتي: 1- استنزاف اقتصاد بلد لصالح بلد آخر . r- انخفاض الدخل القومي في البلد، فبدل أن توظف هذه الأموال وتستثمر في داخل البلد يتم تهريبها إلى الخارج، وإيداعها في مصارف خارجية في حسابات سرية ويظهر ذلك بدرجة ملموسة في كثثر من الدول النامية. r- أن غسيل الأموال يؤدي إلى زيادة نسبة البطالة. ع - أن غسيل الأموال يؤدي إلى سوء توزيع الدخل والثروة. 0- أنه يؤدي إلى انهيار المؤسسات المالية والمصارف، فإن قبول البنوك بإيداع أموال مشبوهة فيها قد يؤدي إلى فزع العملاء الثرعيين وسحب أرصدتهم وأموالهم، مما يؤدي إلى انهيار تلك البنوك. ج-أن عملية غسيل الأموال تؤدي إلى تشويه المنافسة داخل القطاع المالي، وتبقى مقتصرة بصورة مصطّّعة على نشاط بعض المؤسسات المالية 


\section{المقاصد الثرعية المرعية}

الضعيفة التي تتأثز بإغراءات المبيضين والمنظمات الإجرامية، مما يؤدي إلى الى المئ

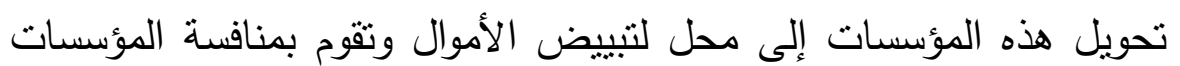
المالية الأخرى بطريقة غير مشروعة (1).

المطلب الرابع: في بيان المقصد الرابع: وهو عمارة الأرض والسعي إلى تحقيق

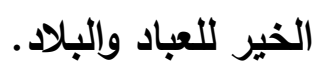

فهذا المقصد من أهم المقاصد التي قد عني بها الاقتصاد الإسلامي، الإل، الإداء

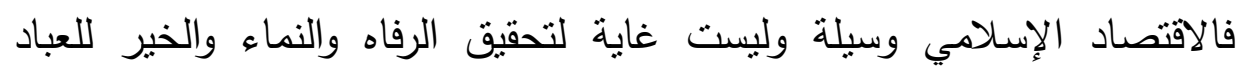
والبلاد، والمال في الإسلام وسيلة لا غاية: فهو وسيلة للعيش الكريم، ولتلبية الحاجات، ومساعدة الناس، لذلك ذم الإسلام حب المال الثال الثديد والتعلق به، قال تعالى: " وتُحبون المال حُباً جماً"(r)، ولكنه لم يمنع من التنتع به، وإنفاقه بما

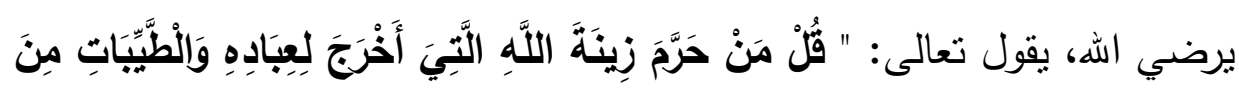

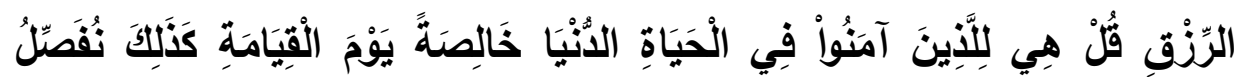

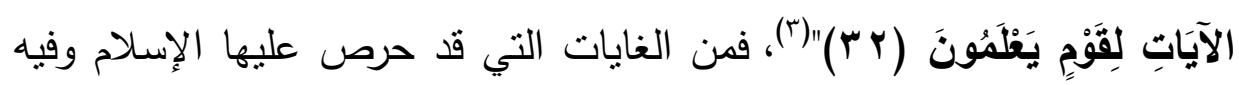
يتحقق النماء والازدهار في أي اقتصاد:

1-القضاء على البطالة: فقد كره الإسلام البطالة، وحث على التهل العمل الثُّريف

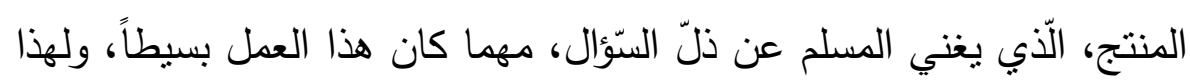

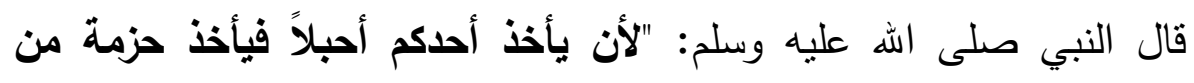
حطب فيبيع فيكف الله به وجهه خير من أن يسأل الناس أعطي أم منع" (ع).

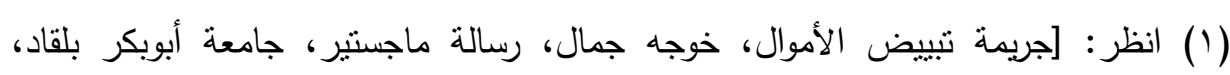

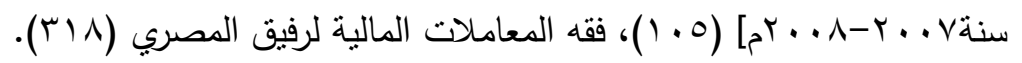

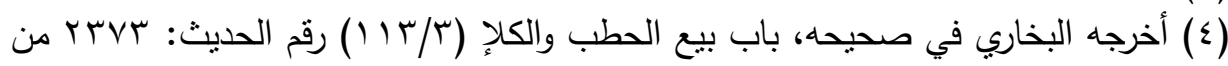
حليث الزبير بن العوام رضي الله عنه. 
د. أحمد نبيل محمد الحسينان عـ

فمن الآثار السلبية للبطالة من الناحية الاقتصادية: أ - أن البطالة عامل من عوامل التخلف الاقتصادي؛ وذلك لأن البطالة سبب رئيسي في إضعاف الإنتاج الزراعي والصناعي والتجاري. ب -أن البطالة سبب رئيسي للشحناء والعداوة مما ينتج عن ذللك قلة الأعمال والمشاريع النافعة؛ لأن أصحاب الأموال يعتمدون في تتميتها على الربا ويعطلون

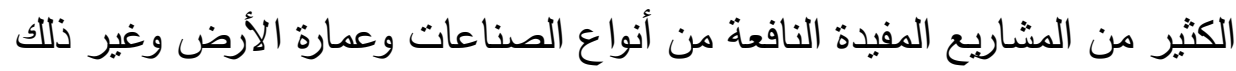
من أنواع الأعمال المفيدة، وقد شرع الله لعباده أنواعاً من المعاملات التي يحصل مل مله بها تبادل المنافع ونمو الثروات والتعاون على كل ما يحقق النفع للمجتمع ويشغل الأبدي العاطلة، ويعين الفقراء على كسب الرزق الحلال والاستغناء عن الربا والتسول(1). (1) (1)

ت - البطالة وإن كانت مقنعة وهي التي تكون فيمن كان موظفاً لدى الدولة ولكن هو في الواقع عاطل عن العمل بسبب إخلاله به يكون سبب إبطاء عجلة الإنتاج، وعدم القيام بوظيفته على أكمل وجه(r). ث- - أن البطالة تسبب عبئًا على بيث مال المسلمين، نظراً لكثرة ما تتفقه الدولة على العاطلين(r).

المطلب الخامس : في بيان المقصد الخامس: تحقيق القوة الاقتصادية والسعي إلى تعزيزها:

تحقيق القوة هي غاية أي دولة من الدول، سواء كانت قوة عسكرية أو اجتماعية أو قوة اقتصادية، وتحقيق القوة غاية دعانا إليه الدين الإسلاهي، ومن

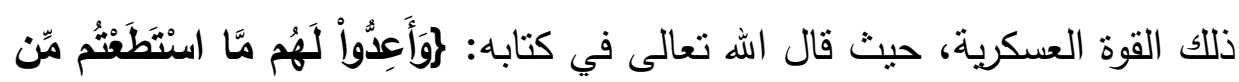

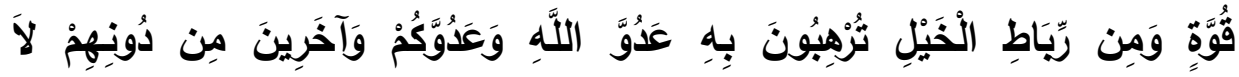

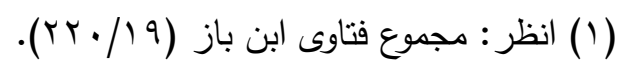

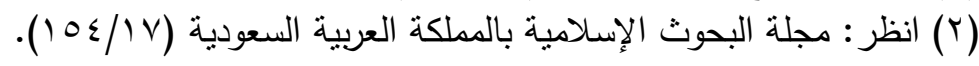

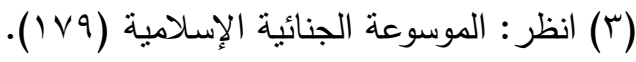




\section{المقاصد الثرعية المرعية - (المية}

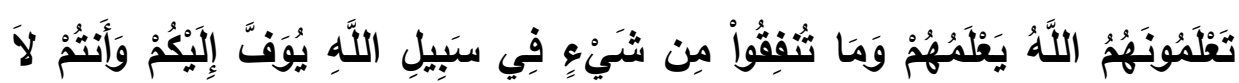

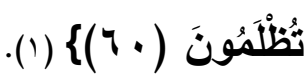

وقد دعت الثريعة الإسلامية أيضاً إلى تحقيق سبل القوة والتآلف الاجتماعي، الني،

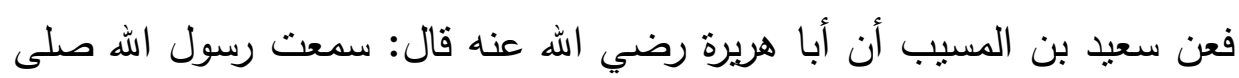
اله عليه وسلم يقول:" حق المسلم على المسلم خمس رد السلام وعيادة المريض المئ

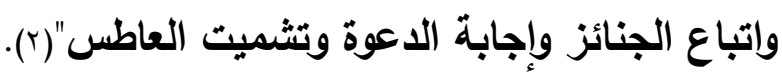

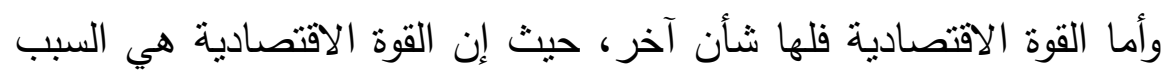

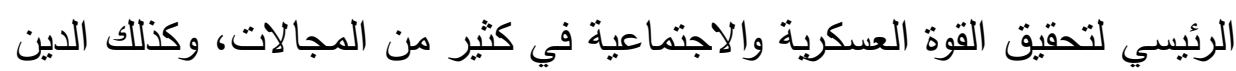

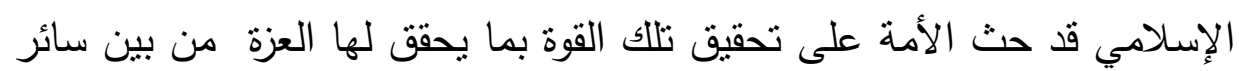
الأمم، فمن الأمور الني دعانا إليه الثرع لتحقيق القوة الإنة الاقتصادية ما بأني:

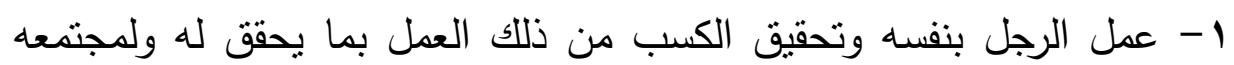

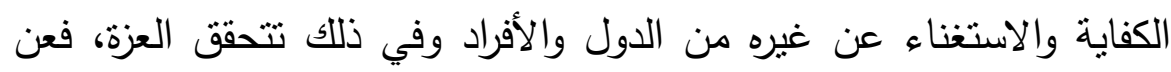

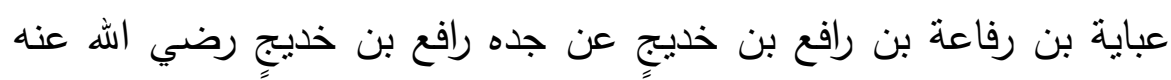

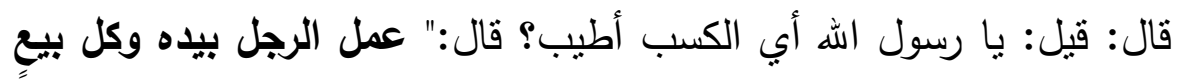
مبرورٍ" (r)، قال بدر الدين العيني في شرحه هذا الحديث: وذاك أفضل من حيث الانتفاع العام فهو نفع متعدّ إلى غيره وإذا كان كذلك فينبغي أن يختلف الحال في ذلك باختلاف حاجة الناس (\&).

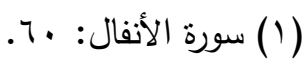

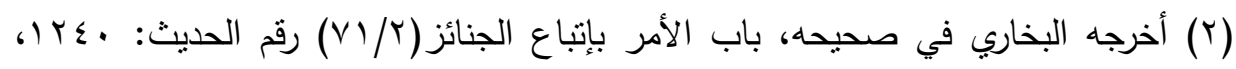

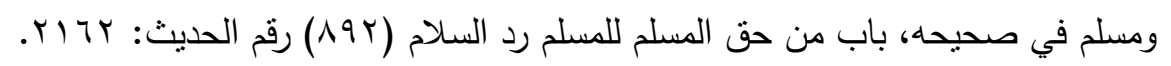

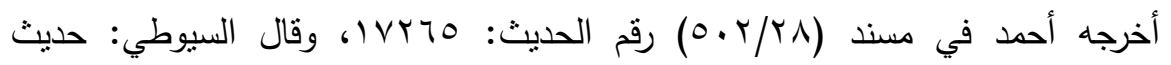

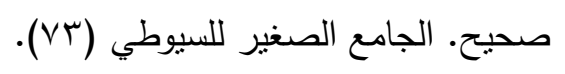
(4) انظر : عدة القاري في شرح صحيح البخاري (Y/Y/Y) (Y). 
د. - أحمد نبيل محمد الحسينان عـ

r - استغلال الموارد البشرية والطبيعية المتوافرة، واستعمال كل شيء منها على حسب ما خلق ووضع له، وبذلك تتحقق القوة الاقتصادية؛ لأنه لو استخل أي ولي مورد في غير ما يمكن الانتفاع به لأدى ذلك إلى فساد ذلك المورد وأدى أيضاً إلى ضياع جهد العامل، وهذا وقد دعتنا الثربعة الإسلامية إلى إلى استخلال الموارد على حسب ما خلقت له وعلى حسن ما وضعت له، ومثال ذلك ما بأتي:

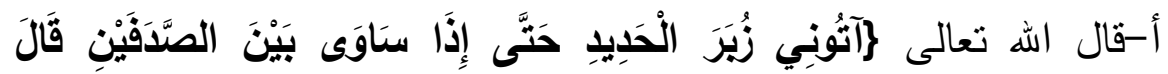

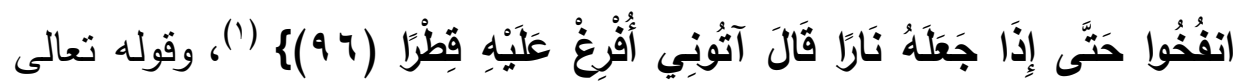

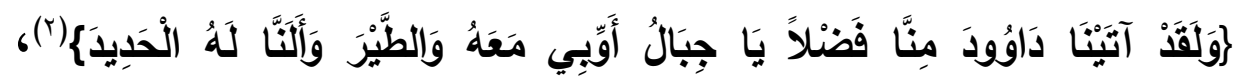
فهاتين الآيتين تدلان على أن الحديد إنما خلق للبناء(ّ).

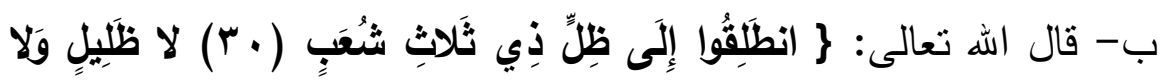

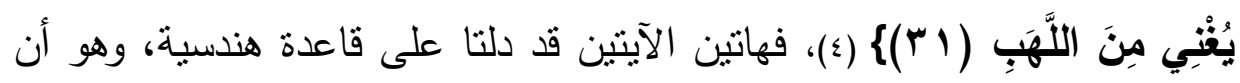
الشكل المنلث لا ظل له، فهذا من استغلال القواعد الهندسية بالشكل المطلوب والمفيد بما يحقق النماء الاقتصادي(ه).

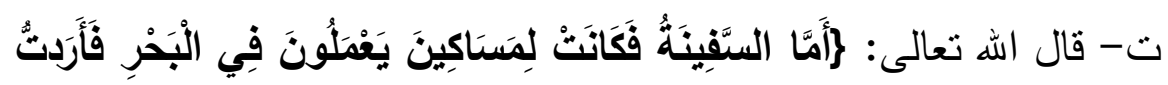

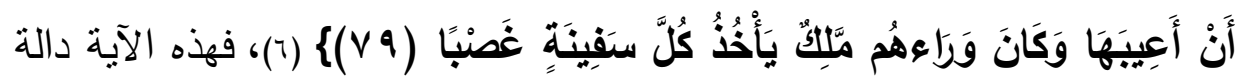
على أن السفينة إنما تستخل وتنتخدم في التتقل البحري، ومما لا شك فيه أن استخلالها في التتقل البحري تتحقق به القوة الاقتصادية.

$$
\begin{aligned}
& \text { (1) سورة الكهف: } 97 .
\end{aligned}
$$

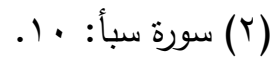

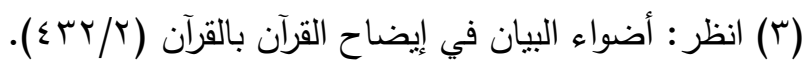

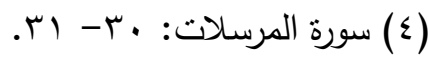

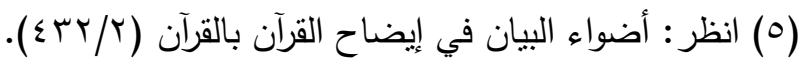

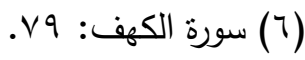




\section{المقاصد الثرعية المرعية}

وذلك بنقل البضائع من بلد إلى بلد، مما يحقق العائد المالي للبائع

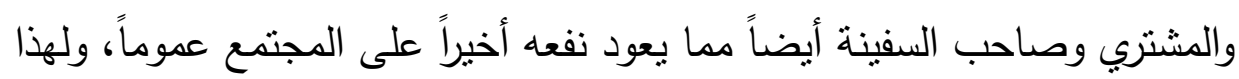

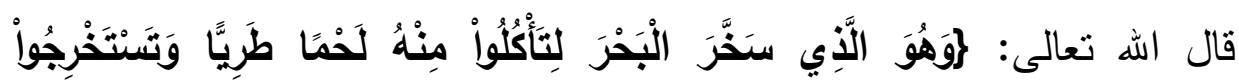

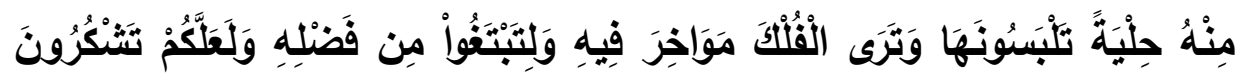

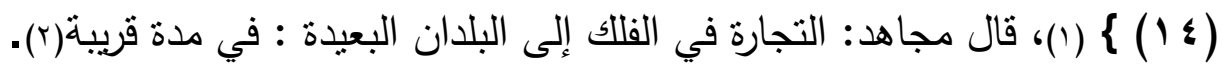
r- الاهتمام بالابتكارات والعلوم الحديثة التي يكون لها الأثر في تحقيق النماء

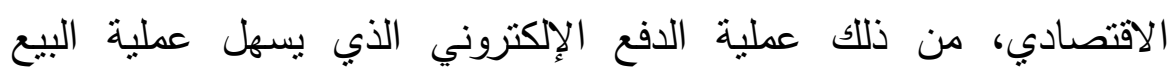

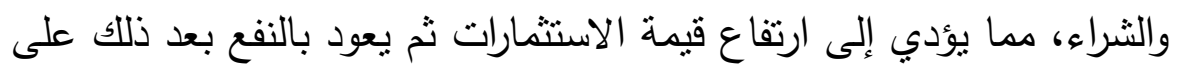

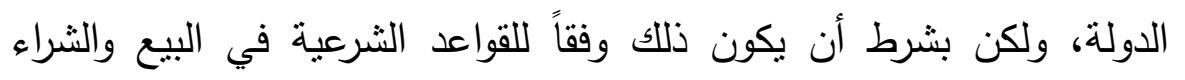
وعلى حسب نوع البطاقة، كما أن الأصل هو جواز التعامل بها؛ لأن العميل

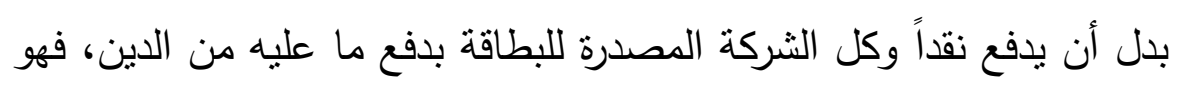

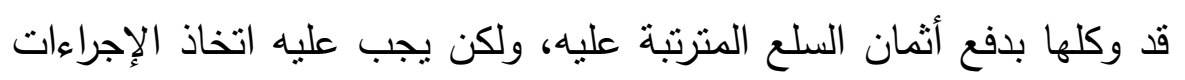

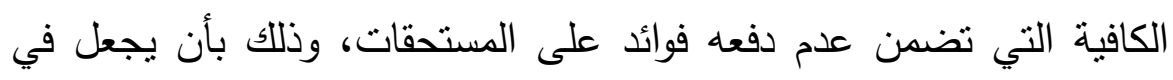

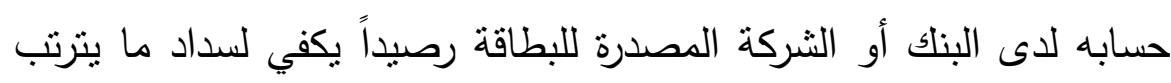
عليه (广).

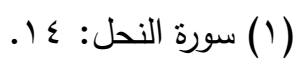

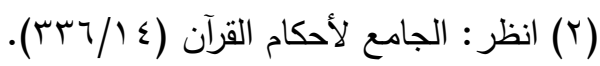

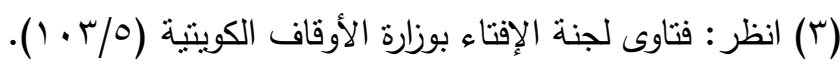

$$
\begin{aligned}
& -r q r-
\end{aligned}
$$


د. أحمد نبيل محمد الحسينان لــ

الخاتمة:

الحمد لله رب العالمين، والصلاة والسلام على أشرف الأنبياء والمرسلين، نبينا محمد، وعلى آله وصحبه أجمعين، أما بعد:

فإن الله تعالى ما خلق هذا الخلق العظيم إلا لحكمة عظيمة ألا وهي عبادته وعدم الإشراك به، وكذلك لم يشرع الأحكام الثرعية إلا لغاية وهي تحقيق العبودية، وكذلك لم يحل البيع ويحرم الربا إلا لمقصد وغاية وحكمة، فمن خلال التعامل بالبيوع التي أحلها الله تعالى يتحقق الازدهار والنماء في الاقتصاد الإسلامي، فالاقتصاد الإسلامي له مقاصد شرعية يتحقق بها التكامل، وقد اجتهدت من خلال هذا البحث في استتباط بعض تلك المقاصد الثرعية، وهي كما بأتي:

المقصد الأول: تحقيق العدالة الاجتماعية بين أفراد المجتمع، ويتحقق ذلك بما يأتي: 1- تسعير السلع والخدمات بضوابط وشروط تتحقق معها العدالة الاجتماعية بين أفراد المجتمع الواحد. r- تجنب احتكار السلع قدر الإمكان.

المقصد الثاني: تحقيق التوازن بين مصلحة الفرد ومصلحة الجماعة ويتبين ذلك من خلال: - 20 - 20

ا- تتوع مصارف الزكاة المراد صرفها لأفراد المجتمع المستحقين لها. r- إعانة الصناع وتدريبهم على الإنتاج والصناعة. r- إقرار مبدأ الملكية المزدوجة، ويدخل فيها: 


\section{=}

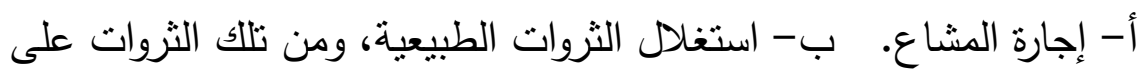

$$
\text { وجه الخصوص الثروات المعدنية والمائية. }
$$

المقصد الثالث: تفعيل الرقابة الذاتية في المعاملات المالية، ويكون ذلكاتك

$$
\text { بما يأتي: }
$$

1- تجنب الغش في المعاملات المالية بصورها القديمة والحديثة.

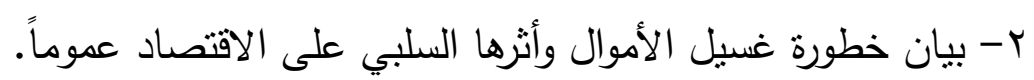

المقصد الرابع: عمارة الأرض والسعي إلى تحقيق الخير للعباد والبلاد،

ويتحقق ذلك:

بالقضاء على البطالة قدر الإمكان.

المقصد الخامس: تحقيق القوة الاقتصادية والسعي إلى تعزيزها: ويتحقق لأنق

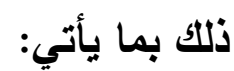

1- عمل الرجل بنفسه وتحقيق الكسب من ذلك العمل بما يحقق له ولمجتمعه

الكفاية والاستغناء عن غيره من الدول والأفراد وفي ذلك تتحقق العزة.

r- استغلال الموارد البشرية والطبيعية المنوافرة.

r- الاهتمام بالابتكارات والعلوم الحديثة التي يكون لها الأثر الإيجابي في تحقيق العيق

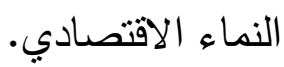


د. د أحمد نبيل محمد الحسينان عـ بـ

\section{المصادر والمراجع}

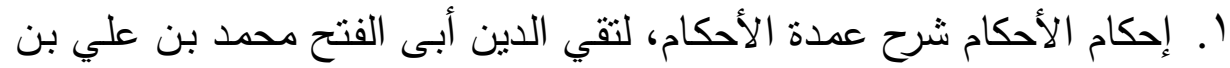
وهب بن مطيع القشيري ، المعروف بابن دقيق العيد (ت : r • Vه)، تحقيق :

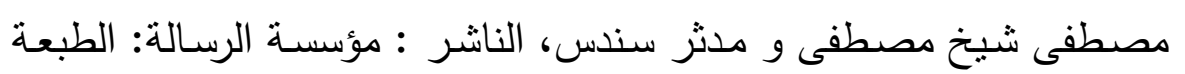

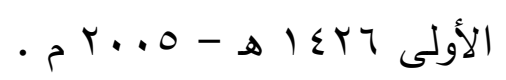

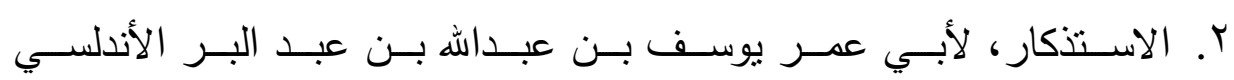

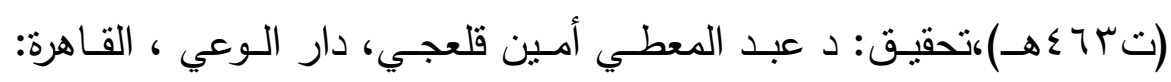

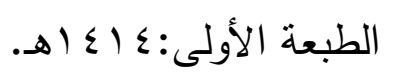

r. الأسس النظرية للاقتصـاد الإسـامي، لخالد المقرن، بدون دار نشر، الطبعة

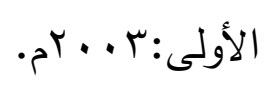

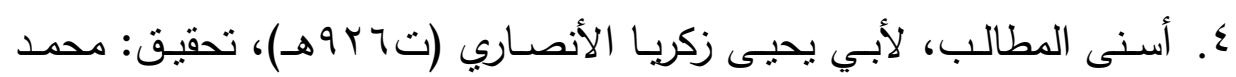

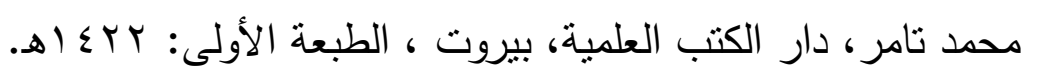

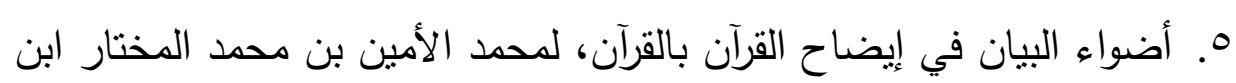

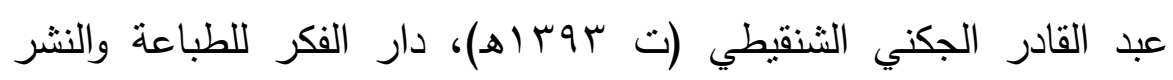

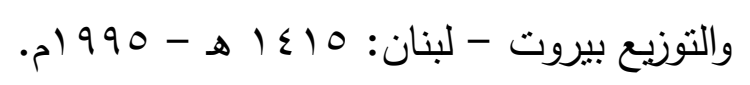

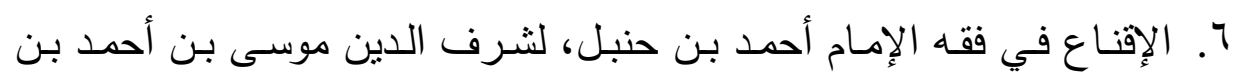

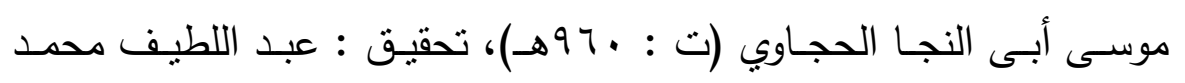

$$
\text { موسى السبكي، الناشر : دار المعرفة بيروت - لبنان. }
$$

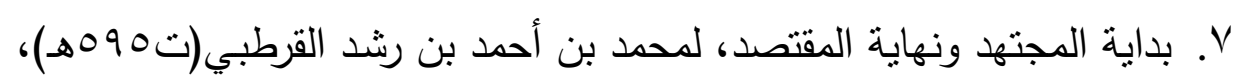

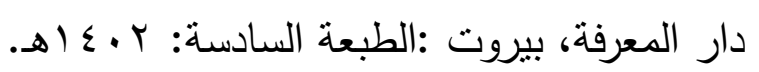

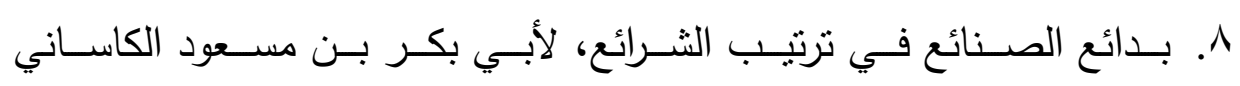

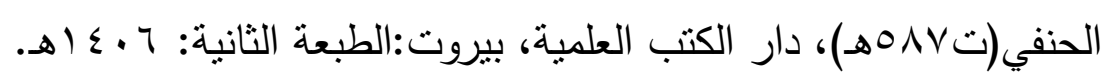




\section{المقاصد الثرعية المرعية}

9. البدر المنير في تخريج الأحاديث والآثار الواقعة في الثرح الكبير، لأبي

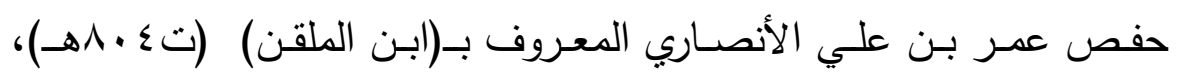

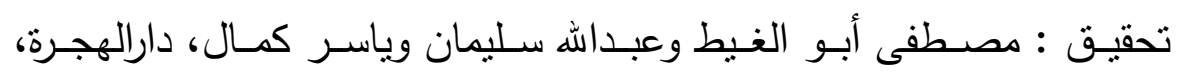

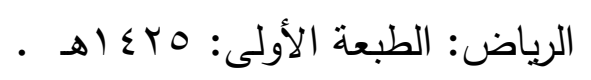

• 1. البناية شرح الهداية، لمحمود بن أحمد بن موسى بن الهمد الهد المعروف (ببدر

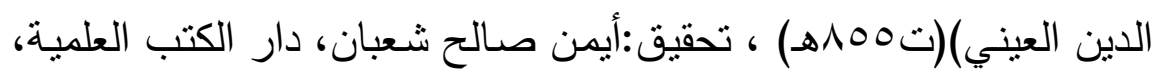

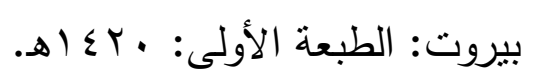

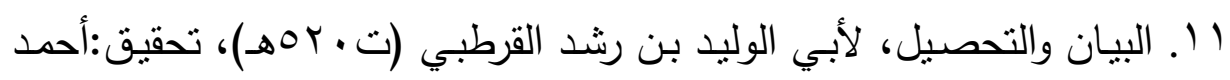

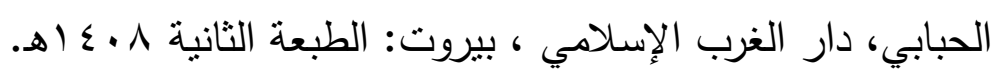

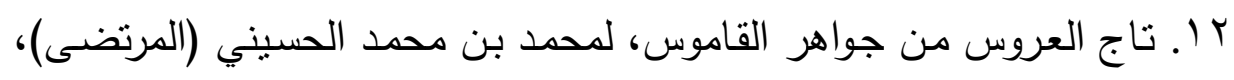

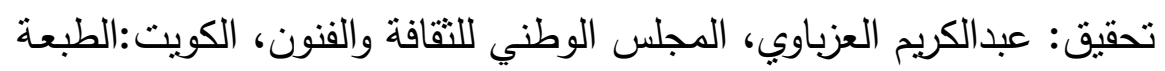

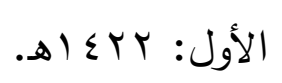

rا. التاج والإكليل لمختصر خليل لهحمد بن يوسف بن أبي القاسم العبدري أبى الهى عبد الله(ت \9هـ)، الناشر دار الفكر، مكان النشر بيروت.

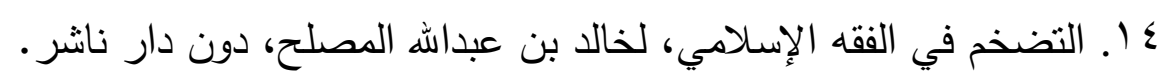

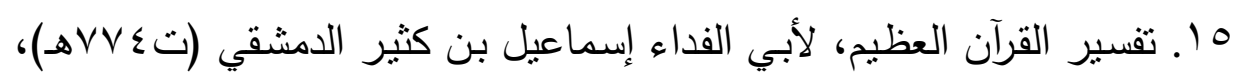
تحقيق: سامي بن محمد سلامة، النانر : دار طيبة للنشر والنتوزيع الطبعة :

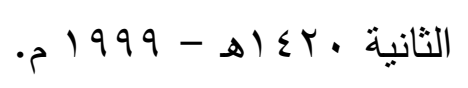

7 ا ـ التنبيه في الفقه الثافعي، لإبراهيم بن علي بن يوسف الفيروزأبادي الثشيرازي

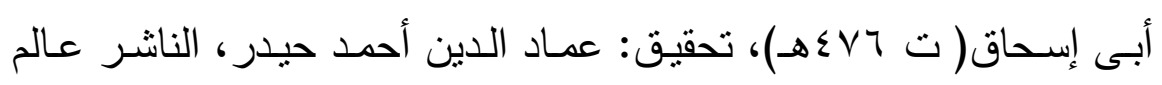

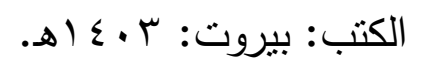

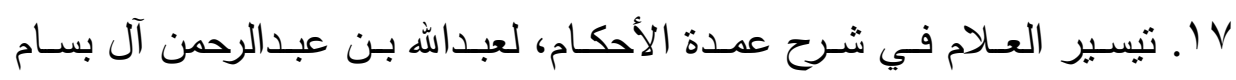

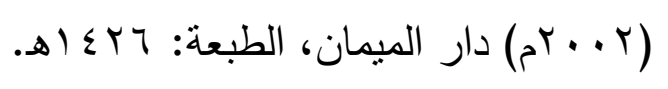


د. · أحمد نبيل محمد الحسينان عـ

1 ا. تيسير الكربم الرحمن في تفسير كلام المنان، لعبد الرحمن بن ناصر بن

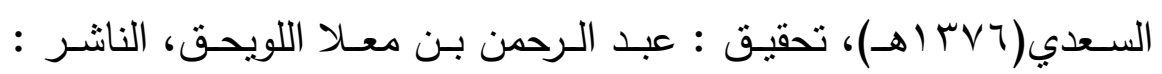

$$
\text { مؤسسة الرسالة، الطبعة : الأولى • بـ اهـ - ... . بم. }
$$

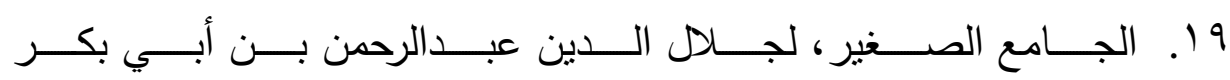

السيوطي(ت ( (9هـ)، دار الكتب العلمية، بيروت، الطبعة الثانية: 0بـ أهـ

•r. الجامع لأحكام القرآن، لأبي عبد الله محمد بن أحمد بن أبي بكر بن فرح

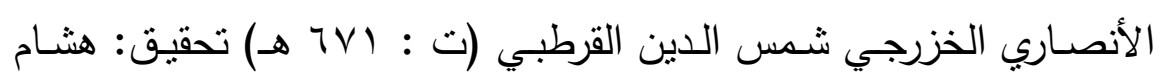

ســير البخـاري، الناثــر : دار عـالم الكتـب، الريـاض، المملكـة العربيـة

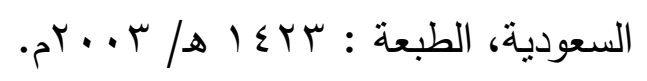

اY. جريمة تبيضض الأموال، لخوجه جمال، رسالة ماجستير، جامعة أبوبكر بلقاد،

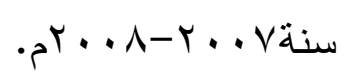

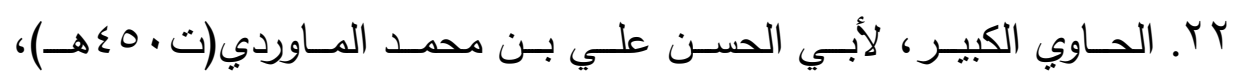
تحقيق:علي محمد معوض وعادل أحمد عبد الموجود، دار الكتب العلمية،

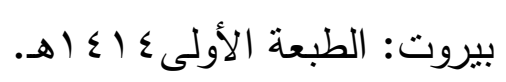

بr. دليل الطالب لنيل المطالب، لمرعي بن يوسف الكرمي(سr • (هـ)، مؤسسـة الرسالة، بيروت، تحقيق: سلطان العيد.

צr. الديباج على صحيح مسلم بن الحجاج، لجلال الدين عبدالرحمن بن أبي بكر

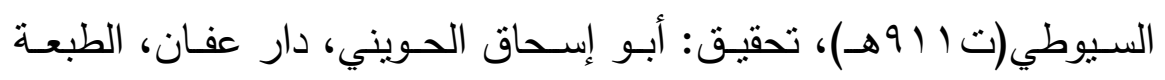

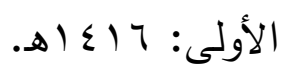

ه. الروض المربع شرح زاد المستقنع، لمنصور بن يونس البهوتي(ت اه ـ (هـ)،

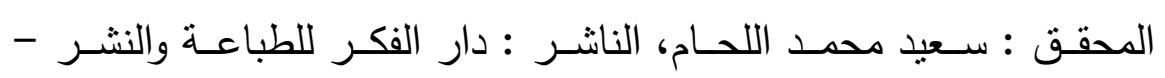

$$
\text { بيروت - لبنان. }
$$




\section{المقاصد الثرعية المرعية}

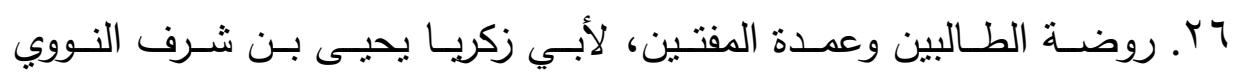

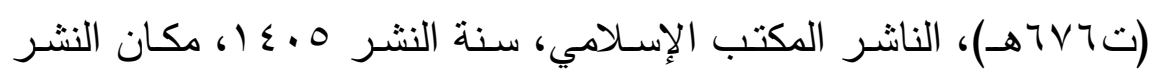

بيروت.

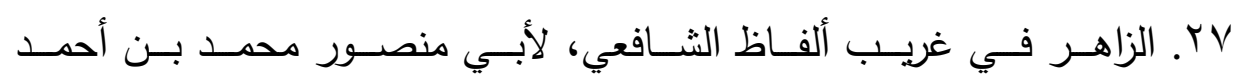

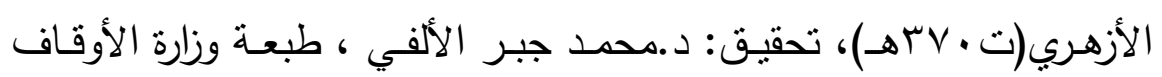

الكويتية.

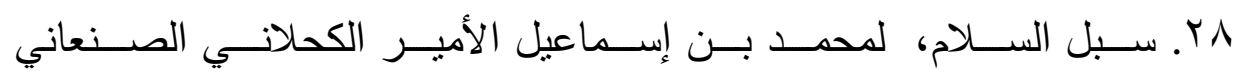

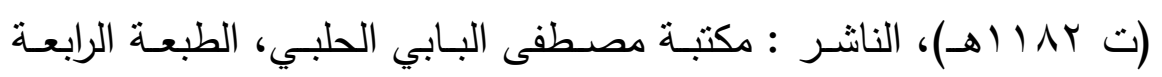

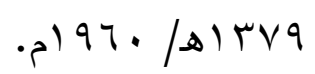

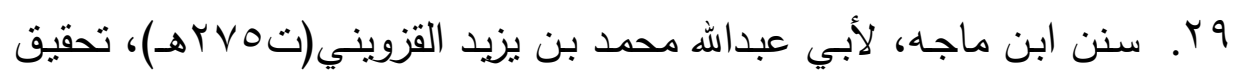

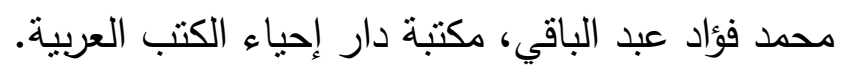

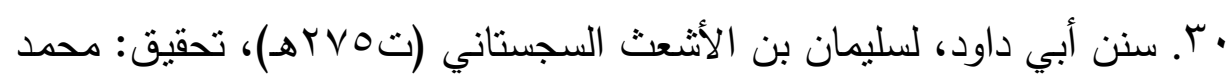

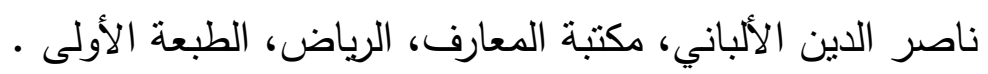

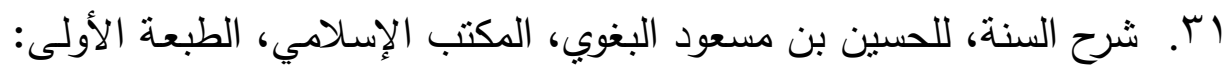
r 9 ام، تحقيق: شعيب الأرناؤوط.

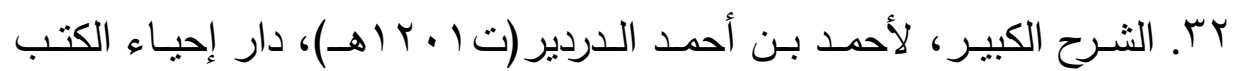
العربية.

باس. الثـرح المتـع على زاد المستقنع، لمحمــ بـن صـالح بـن محمد العثيمين

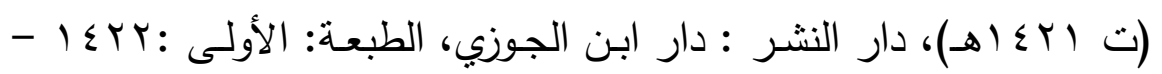
هـ I I Y

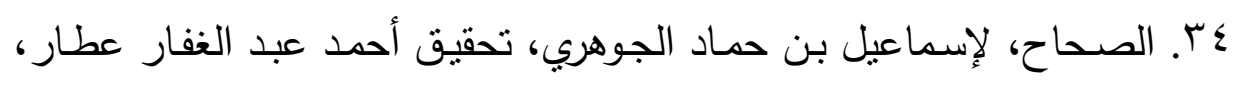

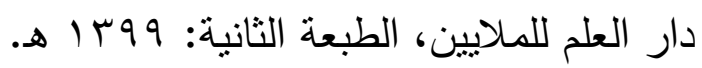




\section{د. أحمد نبيل محمد الحسينان}

هم. صحيح ابن حبان، لمحمد بن حبان بن أحمد التميمي(ت ع هـه)، تحقيق: شعيب الأرناؤوط، مؤسسة الرسالة، بيروت: الطبعة الثانية: ع إئ اله. بr. صحيح البخاري، لأبي عبداله محمد بن إسماعيل البخاري(ت هـهـ)، دار طوق النجاة. rV

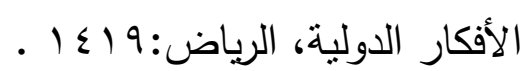
^ץ. الطرق الحكمية في السياسة الثرعية، محمد بن أبي بكر بن أيوب الزرعي المعروف بـ(ابن القيم الجوزية) (ت ال 0 Vه) مطبعة الآداب والمؤبد، مصر . وم. عمدة القاري شرح صحيح البخاري، لبدر الدين العيني الحنفي(ت 100هـ)، دار الكتب العلمية، بيروت: الطبعة الأولى: اب؟ى اهـ. •ع. فتاوى اللجنة الدائمة للإفتاء، مجموعة من العلماء، دار المؤيد، جدة، جمع: أحمد بن عبدالرزاق الدويش.

اءـ فتاوى قطاع الإقتاء بالكويت، مجموعـة مـن العلمـاء، طبعـة وزارة الأوقاف

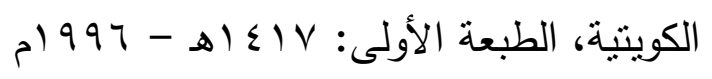

Y ـ ـ فقه المعـاملات الماليـة، لرفيق يـونس المصـري، دار القلم، دمثـق، الطبعـة

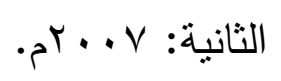

بـ ــ القدرة المائية، لأحمد شفيق الخطيب ويوسف سليمان خيراله، مكتبـة لبنان

$$
\text { ناشرون، الطبعة الأولى: r . . rم. }
$$

؟ ـ. القوانين الفقهيـة، لأبي القاسـ محمد بـن أحمد بـن جزي الكلبي الغرنـاطي المالكي(ت ( § Vه)، تحقيق: محمد بن سبدي، طبعة وزارة الأوقاف الكويتية،

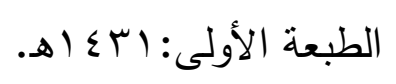

0؛ كثناف القناع عن منن الإقناع، لمنصور بن يونس البهوتي(ت أه ـ (هـ)، تحقيق:هلا مصيلحي، دار الفكر، بيروت: ب ، ع اهـ. 


\section{المقاصد الثرعية المرعية - (المية}

7ـ ـ كثف المخدرات والرياض المزهرات لثرح أخصر المختصرات، لعبد الرحمن

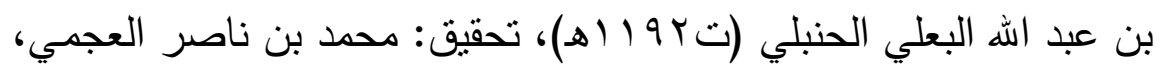

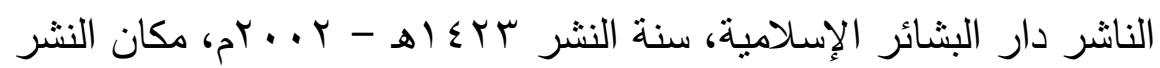

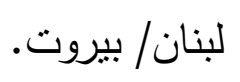

V V كايـة الأخيار في حل غايـة الاختصـار، لأبي بكر بـن محمد الحسيني

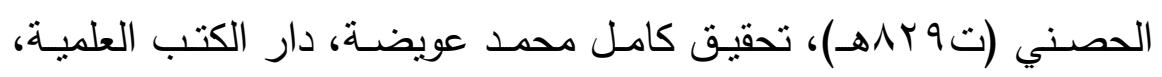

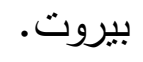

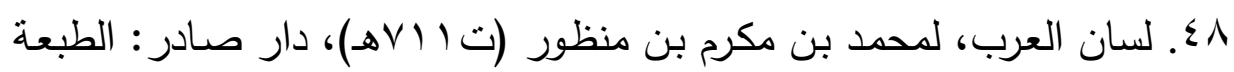

$$
\text { الأولى ، بيروت. }
$$

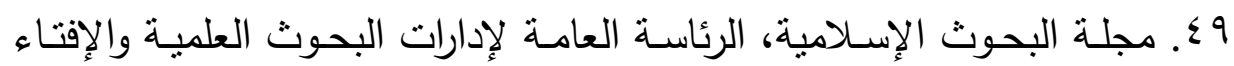
والاعوة والإرثاد. •ـ. مجمـع الأنهر في شـرح ملتقى الأبحر ، لعبداد الرحمن يـن محمد الكليبولي

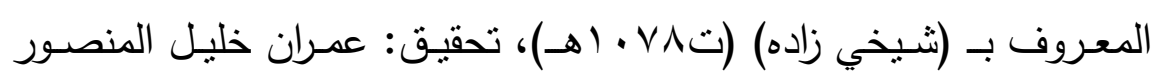
دار الكتب العلمية، بيروت: الطبعة 9 إـأهـ.

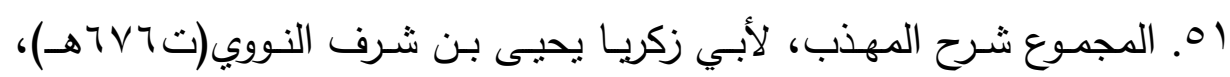
تحقيق: محمد نجيب المطيعي، مكتبة الإرشاد، جدة.

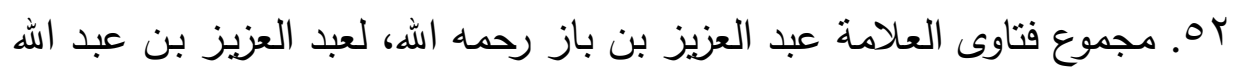

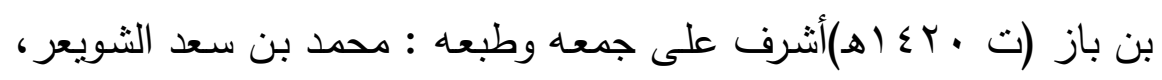
مطبعة الرئاسة العامة للبحوث العلمية والإفتاء.

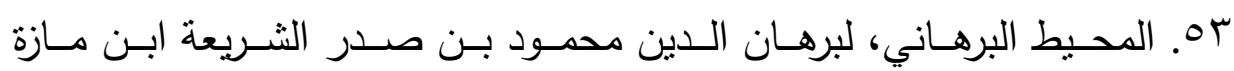

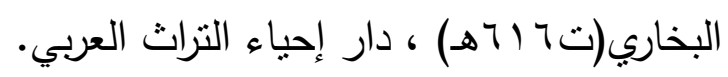

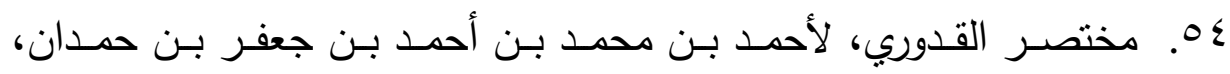

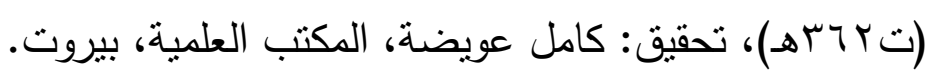


د. أحمد نبيل محمد الحسينان عـ

هـ مرقاة المفاتيح شرح مشكاة المصابيح، علي بن سلطان القاري(ت ع ا ـ (هـ)،

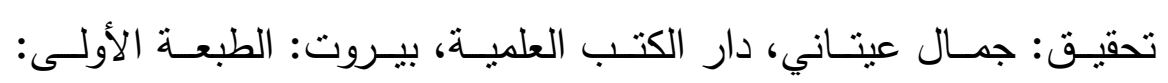

\section{. هـ}

07. مســد أحمـد، لأحمـد بـن محمد بـن حنبـل (ت: (إ بهـ)، تحقيـق: شـعيب

الأرنؤوط وعادل مرشد، مؤسسة الرسالة، بيروت:الطبعة الأولى: 1 ( ـ اهـ.

ov

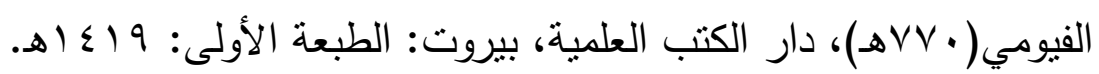

1ه. المصطلحات الفقهية في مذاهب الفقه الإسـلامي، لمحمد أحمد شحاته، دار

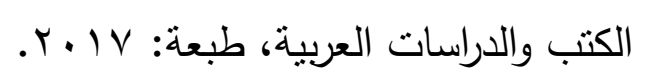

9. معجم المصطلحات الفقهية، قسم الإعداد الفني التابع لقطاع الإفتاء بدولة

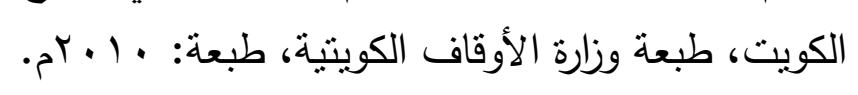

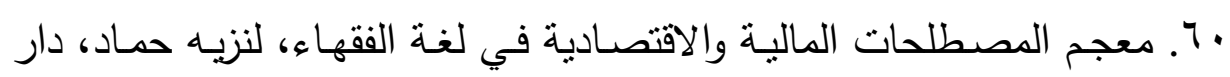

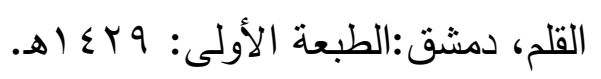

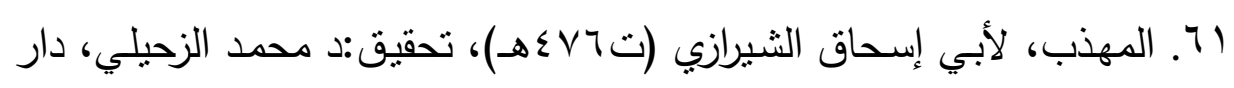

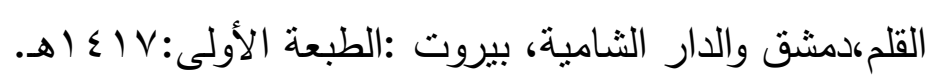

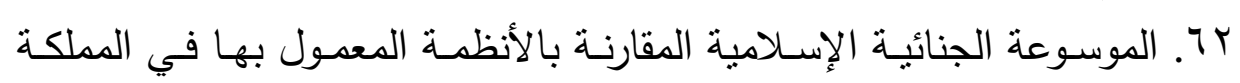

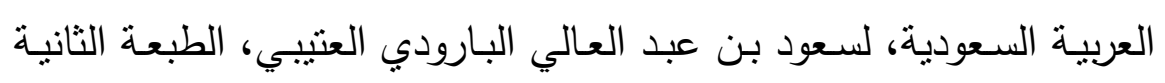

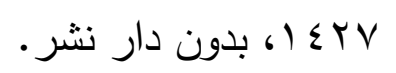

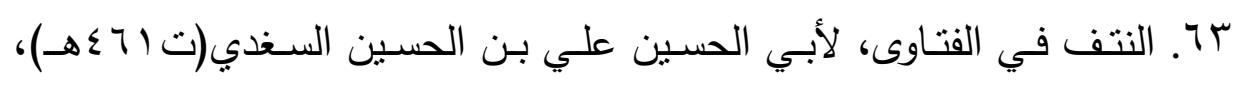
تحقيق المحامي الدكتور صلاح الدين الناهي، الناشر دار الفرقان / مؤسسـة

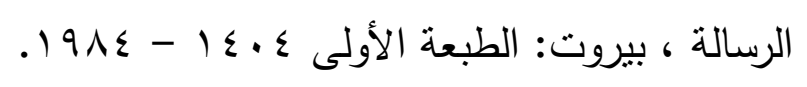

ـ7. الهداية الكافية الثافية، لأبي عبدالله محمد الأنصاري الرصاع (ت عـدهـ)،

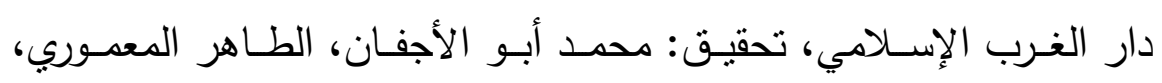

$$
\text { الطبعة الأولى: بو9 } 9 \text { (م. }
$$


=

70. الوسيط في المذهب، لمحمد بن محمد الغزالي(ته . 0هـ)، تحقيق أحمد

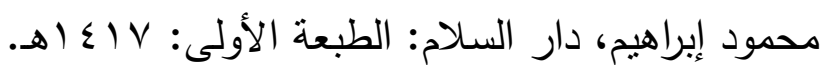

77. يسألونك عن المعاملات المالية المعاصرة، للدكتور حسان الدين بن موسى الدى الداري

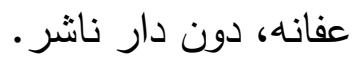

